\title{
The small molecule CA140 inhibits the neuroinflammatory response in wild-type mice and a mouse model of $A D$
}

Ju-Young Lee ${ }^{1}$, Jin Han Nam¹, Youngpyo Nam¹, Hye Yeon Nam¹, Gwangho Yoon', Eunhwa Ko², Sang-Bum Kim², Mahealani R Bautista ${ }^{3}$, Christina C Capule ${ }^{3}$, Takaoki Koyanagi ${ }^{3}$, Geoffray Leriche ${ }^{3}$, Hwan Geun Choi ${ }^{2}$, Jerry Yang ${ }^{3}$, Jeongyeon $\mathrm{Kim}^{1 *}$ and Hyang-Sook Hoe ${ }^{1 *}$ (D)

\begin{abstract}
Background: Neuroinflammation is associated with neurodegenerative diseases, including Alzheimer's disease (AD). Thus, modulating the neuroinflammatory response represents a potential therapeutic strategy for treating neurodegenerative diseases. Several recent studies have shown that dopamine (DA) and its receptors are expressed in immune cells and are involved in the neuroinflammatory response. Thus, we recently developed and synthesized a non-self-polymerizing analog of DA (CA140) and examined the effect of CA140 on neuroinflammation.

Methods: To determine the effects of CA140 on the neuroinflammatory response, BV2 microglial cells were pretreated with lipopolysaccharide (LPS, $1 \mu \mathrm{g} / \mathrm{mL})$, followed by treatment with CA140 (10 $\mu \mathrm{M})$ and analysis by reverse transcription-polymerase chain reaction (RT-PCR). To examine whether CA140 alters the neuroinflammatory response in vivo, wild-type mice were injected with both LPS (10 mg/kg, intraperitoneally (i.p.)) and CA140 (30 mg/ kg, i.p.), and immunohistochemistry was performed. In addition, familial AD (5xFAD) mice were injected with CA140 or vehicle daily for 2 weeks and examined for microglial and astrocyte activation.

Results: Pre- or post-treatment with CA140 differentially regulated proinflammatory responses in LPS-stimulated microglia and astrocytes. Interestingly, CA140 regulated D1R levels to alter LPS-induced proinflammatory responses. CA140 significantly downregulated LPS-induced phosphorylation of ERK and STAT3 in BV2 microglia cells. In addition, CA140-injected wild-type mice exhibited significantly decreased LPS-induced microglial and astrocyte activation. Moreover, CA140-injected 5xFAD mice exhibited significantly reduced microglial and astrocyte activation.
\end{abstract}

Conclusions: CA140 may be beneficial for preventing and treating neuroinflammatory-related diseases, including AD.

Keywords: Alzheimer's disease, Neuroinflammation, D1R, ERK, STAT3, LPS, CA140

\section{Background}

Increasing evidence indicates a critical role of the immune system in neurodegenerative diseases such as Alzheimer's disease (AD) [1]. Abnormal glial activation in patients with neurodegenerative diseases may be a hallmark diagnostic feature of these diseases, particularly AD [2]. Neuroinflammation or inflammation of the central nervous system (CNS) is mainly mediated by the activation of microglia [1]. In addition to releasing various neurotrophic factors that

\footnotetext{
*Correspondence: jykim@kbri.re.kr; sookhoe72@kbri.re.kr

1 Department of Neural Development and Disease, Korea Brain Research Institute (KBRI), 61 Cheomdan-ro, Dong-gu, Daegu 41068, South Korea Full list of author information is available at the end of the article
}

support neuronal cell survival and neurotoxic factors, activated microglia release proinflammatory cytokines such as interleukin-1 $\beta$ (IL-1 $\beta$ ) and tumor necrosis factor- $\alpha$ (TNF- $\alpha$ ) $[3,4]$. The neuroinflammation induced by the release of these proinflammatory cytokines may eventually lead to neuronal cell death and synaptic dysfunction. Therefore, the elucidation of the regulation of glial activation and inactivation may provide a potential therapeutic strategy for treating neurodegenerative diseases.

Lipopolysaccharide (LPS) is a well-established stimulator that induces the activation of microglial cells and is widely used both in vivo and in vitro to induce neuroinflammation in animal models $[5,6]$. The interaction

(c) The Author(s). 2018 Open Access This article is distributed under the terms of the Creative Commons Attribution 4.0 International License (http://creativecommons.org/licenses/by/4.0/), which permits unrestricted use, distribution, and 
between LPS and Toll-like receptor 4 (TLR4) activates inflammation-associated transcription factors [7] and the mitogen-activated protein kinase (MAPK) family [8, 9], which comprises at least three components: extracellular signal-regulated kinases (ERKs), c-Jun N-terminal kinase (JNK), and p38 MAPK. In addition, the association between LPS and TLR4 stimulates the release of both immune-related cytotoxic factors, including iNOS and COX-2, and proinflammatory cytokines (TNF- $\alpha$, IL- $1 \beta$, and IL-6) [10]. A chronic inflammatory response may be accompanied by amyloid beta $(A \beta)$ production, and microglia have been identified near the $A \beta$ plaques of $A D$ patients $[11,12]$. $A \beta$ accumulation triggers $\mathrm{AD}$ pathogenesis through two mechanisms: neuronal apoptosis and glia-mediated inflammation leading to cell death [13]. Extracellular $A \beta$ deposits in senile plaques trigger changes in glial reactivity and stimulate neuroinflammation. Thus, $\mathrm{A} \beta$ accumulation may lead to neuronal loss through the overproduction of reactive proinflammatory cytokines [14, 15]. CA140 is a chemically stable small-molecule analog of dopamine (DA) and is synthesized by acylation of the amine in DA with $\mathrm{N}$-methylisatoic anhydride, which reduces the propensity of DA to undergo self-polymerization [16]. DA is a neurotransmitter that regulates a wide range of functions, including initiation of movement and learning and memory [17]. DA binds to several DA receptors, which are present on nearly all immune cells [18]. Activation of these receptors via DA or DA agonists modulates the activation, proliferation, and cytokine production of immune cells [19]. We therefore speculated that CA140 may also exhibit biological activity against the neuroinflammatory response.

In the present study, we examined whether CA140 regulates the neuroinflammatory response in vitro and in vivo. We discovered that CA140 reduced proinflammatory responses in LPS-stimulated BV2 microglial cells, primary microglial cells, and primary astrocytes. In addition, CA140 inhibited LPS-induced neuroinflammatory responses by inhibiting the dopamine D1 receptor (D1R)/ ERK/STAT3 signaling pathways. Moreover, CA140 significantly decreased the activation of microglia and astrocytes in wild-type mice as well as a mouse model of AD. Taken together, our results indicate that CA140 is a potential therapeutic agent for treating and/or preventing neuroinflammation-related diseases, including AD.

\section{Methods}

\section{Cell lines and culture conditions}

BV2 microglial cells (a generous gift of Dr. Kyung-Ho Suk) or HEK cells (a generous gift of Dr. Hyung-Jun Kim) were maintained in high-glucose DMEM (Invitrogen, Carlsbad, CA, USA) with 5 or $10 \%$ fetal bovine serum (FBS, Invitrogen, Carlsbad, $\mathrm{CA}, \mathrm{USA}$ ) in a $5 \% \mathrm{CO}_{2}$ incubator.

\section{Mouse primary microglial and astrocyte cultures}

Mouse primary microglial and astrocyte cultures were prepared from mixed glial cultures as previously described [20]. Briefly, whole brains of post-natal 1-day-old C57BL/6 mice were chopped and mechanically disrupted using a $70-\mu \mathrm{m}$ nylon mesh. The cells were seeded in $75 \mathrm{~T}$ culture flasks and grown in low-glucose DMEM supplemented with $10 \%$ FBS, 100 unit $/ \mathrm{mL}$ penicillin, and $100 \mu \mathrm{g} / \mathrm{mL}$ streptomycin. The culture medium was changed after 7 days and every 3 days thereafter. After 14 days, mixed primary glial cells were obtained for use in subsequent experiments. To obtain mouse primary astrocytes, mixed glial cells were cultured with shaking at $250 \mathrm{rpm}$ overnight. The next day, the culture medium was discarded, and the cells were washed three times with PBS. The cells were dissociated using trypsin-EDTA and collected by centrifugation at $1200 \mathrm{rpm}$ for $10 \mathrm{~min}$. Primary astrocytes were maintained in low-glucose DMEM supplemented with 10\% FBS and penicillin-streptomycin. To obtain mouse primary microglial cells, mixed primary glial cells were incubated with trypsin solution $(0.25 \%$ trypsin, $1 \mathrm{mM}$ EDTA in Hank's balanced salt solution) diluted 1:4 in serum-free DMEM media [21]. After the mouse primary astrocyte layer was fully detached, low-glucose DMEM containing 10\% FBS was added, the supernatant was aspirated, and the remaining primary microglial cells were used for experiments.

\section{Rat primary microglial and astrocyte cultures}

Rat primary mixed glial cells were cultured from the cerebral cortices of 1-day-old Sprague Dawley rats. Briefly, the cortices were triturated into single cells in high-glucose DMEM containing 10\% FBS/penicillin-streptomycin solution (5000 units $/ \mathrm{mL}$ penicillin, $5 \mathrm{mg} /$ $\mathrm{mL}$ streptomycin, Corning, Mediatech Inc., Manassas, VA, USA) and plated into $75 \mathrm{~T}$ culture flasks ( $0.5 \mathrm{hemi-}$ sphere/flask) for 2 weeks. To harvest rat primary microglial cells, the plate was shaken continuously at $120 \mathrm{rpm}$ for $2 \mathrm{~h}$ to facilitate microglial detachment from the plate. The fluid medium was subsequently collected and centrifuged at $1500 \mathrm{rpm}$ for $15 \mathrm{~min}$, and the cell pellets were resuspended to plate $1 \times 10^{5}$ cells per well. The remaining cells in the flask were harvested using $0.1 \%$ trypsin to obtain rat primary astrocytes. These rat primary astrocytes and primary microglial cells were cultured in 12-well plates $(35 \mathrm{~mm})$ pre-coated with poly-D-lysine (Sigma).

\section{Wild-type mice}

All experiments were performed in accordance with the approved animal protocols and guidelines established by the Korea Brain Research Institute (IACUC-2016-0013). C57BL6/N mice were purchased from Orient-Bio 
Company. Male C57BL6/N mice (8 weeks, 25-30 g) were housed in a pathogen-free facility with $12 \mathrm{~h}$ of light and dark per day at an ambient temperature of $22{ }^{\circ} \mathrm{C}$. To determine if pretreatment with CA140 alters LPS-induced neuroinflammation, wild-type mice were intraperitoneally (i.p.) administered CA140 (30 mg/kg) or vehicle (10\% DMSO) daily for 3 days and subsequently injected with LPS (Sigma, Escherichia coli, $10 \mathrm{mg} / \mathrm{kg}$, i.p.) or PBS. After $3 \mathrm{~h}$, immunostaining was performed with anti-IbaI or anti-GFAP antibodies. To examine whether post-treatment with CA140 regulates LPS-induced neuroinflammatory responses, wild-type mice were injected with LPS (10 mg/kg/day, i.p.) or PBS, followed $30 \mathrm{~min}$ later by injection with CA140 $(30 \mathrm{mg} /$ $\mathrm{kg}$, i.p., twice with an interval of $1 \mathrm{~h}$, followed $30 \mathrm{~min}$ later by a third injection) or vehicle (10\% DMSO, i.p.). Immunohistochemistry was then performed with anti-Iba-1 and anti-GFAP antibodies.

\section{Familial AD (5xFAD) mice}

F1 generation 5xFAD mice (stock number 008730, B6SJL-Tg APPSwFlLon, PSEN1*M146 L"L286V6799Vas/ Mmjax) were purchased from The Jackson Laboratory. 5xFAD mice overexpress two mutant human proteins: APP (695) with KM670/671NL (Swedish), I716V (Florida), and V717I (London) FAD mutations and PS1 with M146 L and L286 V FAD mutations. To examine the effects of CA140 on the neuroinflammatory response in a mouse model of AD, 5xFAD mice were injected with CA140 (30 mg/kg, i.p.) or vehicle (10\% DMSO, i.p.) daily for 2 weeks, and immunohistochemistry was conducted with anti-Iba-1 or anti-GFAP antibodies. The animal groups were randomized for all experiments. Data were analyzed in a semi-automated manner using ImageJ software and confirmed by an independent researcher who did not participate in the current experiments. Only male mice were used for this study because the pathology of 5xFAD female mice is more severe than that of male mice, leading to huge variations in in vivo experiments.

\section{Synthesis of CA140}

$N$-Methylisatoic anhydride (19.6 mg, $110 \mu \mathrm{mol})$ was added to $28.1 \mathrm{mg}$ of 3,4-dimethoxyphenethylamine (155 $\mu \mathrm{mol}, 1.3$ equiv) and $25 \mu \mathrm{L}$ of triethylamine (339 $\mu \mathrm{mol}, 3$ equiv) in dichloromethane (DCM). The reaction mixture was stirred for $2 \mathrm{~h}$ at room temperature and overnight at $20{ }^{\circ} \mathrm{C}$. The mixture was warmed to room temperature, and a vacuum was subsequently applied to remove volatile organics. The amide product was purified by column chromatography (7\% ethyl acetate in $\mathrm{DCM} ; \mathrm{Rf}=0.27)$ to provide $31.5 \mathrm{mg}$ of $N$-(3,4-dimethoxyphenethyl)-2-(methylamino)benzamide as a white solid $\left(91 \%\right.$ isolated yield). ${ }^{1} \mathrm{H}-\mathrm{NMR}$ $\left(400 \mathrm{MHz}, \mathrm{CDCl}_{3}\right) \delta \mathrm{ppm}=7.30(\mathrm{t}, 1 \mathrm{H}, J=7.7 \mathrm{~Hz}$, Ar-H), 7.20 (d, 1H, J = 7.7 Hz, Ar-H), $6.82(\mathrm{~d}, 1 \mathrm{H}, J=$ $8.1 \mathrm{~Hz}, \mathrm{Ar}-\mathrm{H}), 6.74(\mathrm{~m} 2 \mathrm{H}, \operatorname{Ar}-\mathrm{H}), 6.55(\mathrm{t}, 1 \mathrm{H}, J=$ $7.5 \mathrm{~Hz}, \mathrm{Ar}-\mathrm{H}), 3.86\left(\mathrm{~s}, 3 \mathrm{H}, \mathrm{OCH}_{3}\right), 3.83\left(\mathrm{~s}, 3 \mathrm{H}, \mathrm{OCH}_{3}\right)$, $3.63(\mathrm{t}, 1 \mathrm{H}, J=6.7 \mathrm{~Hz},-\mathrm{HCH}-), 3.61(\mathrm{t}, 1 \mathrm{H}, J=6.7 \mathrm{~Hz}$, $-\mathrm{HCH}-), 2.84\left(\mathrm{~s}, 3 \mathrm{H}, \mathrm{CH}_{3}\right), 2.84\left(\mathrm{t}, 2 \mathrm{H}, J=6.8 \mathrm{~Hz}, \mathrm{CH}_{2}\right)$. ${ }^{13} \mathrm{C}-\mathrm{NMR}\left(100 \mathrm{MHz}, \mathrm{CDCl}_{3}\right) \delta \mathrm{ppm}=169.6,150.0$, $148.9,147.6,132.7,131.4,127.0,120.6,115.4,114.8$, 111.9, 111.4, 111.3, 55.8, 55.7, 40.9, 35.1, 29.8.

$\mathrm{N}$-(3,4-Dimethoxyphenethyl)-2-(methylamino)benzamide $(9.2 \mathrm{mg}, 29.3 \mu \mathrm{mol})$ was dissolved in $0.5 \mathrm{~mL}$ of anhydrous $\mathrm{DCM}$, and $120 \mu \mathrm{L}$ of $1 \mathrm{M} \mathrm{BBr}_{3}$ in $\mathrm{DCM}$ (120 $\mu \mathrm{mol}, 4$ equiv) was added. The reaction was stirred overnight under an inert atmosphere. Excess methanol was added to the mixture, and volatile organics were removed in vacuo. The addition and removal of methanol was repeated at least three times to remove boric acid as methyl borate. The target compound, $N$-(3,4-dihydroxyphenethyl)-2-(methylamino)benzamide (CA140), was obtained in quantitative yield. ${ }^{1} \mathrm{H}-\mathrm{NMR}(400 \mathrm{MHz}$, $\left.\mathrm{CD}_{3} \mathrm{OD}\right) \delta \mathrm{ppm}=7.91(\mathrm{~d}, 1 \mathrm{H}, J=8.0 \mathrm{~Hz}, \mathrm{Ar}-\mathrm{H}), 7.89(\mathrm{t}$, $1 \mathrm{H}, J=7.6 \mathrm{~Hz}, \mathrm{Ar}-\mathrm{H}), 7.74(\mathrm{~m}, 2 \mathrm{H}, J=7.6 \mathrm{~Hz}, \mathrm{Ar}-\mathrm{H})$, $6.67(\mathrm{~d} 2 \mathrm{H}, J=9.6 \mathrm{~Hz}$ Ar-H), $6.56(\mathrm{~d}, 1 \mathrm{H}, J=8.0 \mathrm{~Hz}$, Ar-H), 3.60 (t, $2 \mathrm{H}, J=7.1 \mathrm{~Hz}, \mathrm{CH}_{2}$ ), 3.01 (s, 3H, $\mathrm{NCH}_{3}$ ), $2.79\left(\mathrm{t}, 1 \mathrm{H}, J=7.0 \mathrm{~Hz}, \mathrm{CH}_{2}\right)$. LC-MS ESI positive mode $m / z[\mathrm{M}+\mathrm{H}]^{+}=287.11$ (calculated $\left.=287.13\right)$.

\section{Brain-to-plasma ratio in ICR (Institute for Cancer Research) mice}

ICR mice $(n=3)$ were dosed with CA140 dissolved in DMSO/Tween-80/saline (10:5:85\%) via a single intravenous administration $(10 \mathrm{mg} / \mathrm{kg})$. Blood was collected by cardiac puncture at $5 \mathrm{~min}$ and then centrifuged to isolate plasma. The brain was collected at $5 \mathrm{~min}$ and homogenized in PBS after washing with fresh PBS. The concentrations of CA140 in the plasma and brain were determined by LC-MS/MS. The LC-MS/MS system comprised a Nexera XR HPLC system (Shimadzu Co., Kyoto, Japan) coupled to a TSQ Vantage triple quadrupole mass spectrometer equipped with Xcalibur version 1.1.1 (Thermo Fisher Scientific Inc., Waltham, MA, USA).

\section{Stability studies of CA140 and dopamine in vitro}

To examine the stability of CA140 in vitro, samples were generated from stock solutions (30 $\mathrm{mM}$ in DMSO) of either dopamine (DA, as a control for CA140) or CA140 by dilution in $1 \mathrm{~mL}$ of preheated PBS buffer to yield final concentrations of $500 \mu \mathrm{M}$. The solutions were incubated at $37{ }^{\circ} \mathrm{C}$ in a thermoblock, and the concentration of CA140 or DA was followed over time in triplicate. Aliquots $(50 \mu \mathrm{L})$ were taken at $0,1,2,4,6,8$, and $22 \mathrm{~h}$ and added to $200 \mu \mathrm{L}$ of acetonitrile. The samples were mixed by vortexing for $30 \mathrm{~s}$ and then centrifuged at $4{ }^{\circ} \mathrm{C}$ for $15 \mathrm{~min}$ at $14,000 \mathrm{rpm}$. The clear supernatants were 
diluted in PBS (2-fold) and analyzed by HPLC at 254 and $280 \mathrm{~nm}$ for CA140 and DA, respectively.

\section{Antibodies and inhibitors}

The following primary antibodies were used throughout this study: rat anti-mouse CD11b (1:400, Abcam), rabbit anti-F-actin (1:1000, Abcam), rabbit anti-COX-2 (1:1000, Abcam), rabbit anti-IL-1 $\beta$ (1:200, Abcam), rabbit anti-GFAP (1:5000, Neuromics), rabbit anti-Iba-1 (1:1000, Wako), goat anti-Iba-1 (1:500, Wako), rabbit anti-AKT (1:1000, Santa Cruz), rabbit anti-p-AKT (Ser473, Thr308) (1:1000, Cell Signaling), rabbit anti-ERK (1:1000, Santa Cruz), rabbit anti-p-ERK (Thr42/44) (1:1000, Cell Signaling), rabbit anti-STAT3 (1:1000, Cell Signaling), rabbit anti-p-STAT3 (Ser727, Abcam), mouse anti-PCNA (1:1000, Santa Cruz), rabbit anti-D2R (1:1000, Abcam), and rabbit anti-D1R (1:1000, Millipore) antibodies. We used the following small molecules: D1R antagonists (LE300, $10 \mu \mathrm{M}$, Sigma-Aldrich; SCH23390, $30 \mu \mathrm{M}$, Tocris), D1R agonist (A77636 hydrochloride, $10 \mathrm{nM}$, Tocris), D2R antagonist (eticlopride hydrochloride, $100 \mathrm{nM}$, Sigma-Aldrich), a STAT3 inhibitor (S3I-201, $50 \mu \mathrm{M}$, Sigma-Aldrich), and an ERK inhibitor (PD98059, $10 \mu \mathrm{M}$, Millipore).

\section{MTT assay}

BV2 microglial cell viability was assessed using the 3-(4,5-dimethylthiazol-2-yl)-2,5-diphenyltetrazolium

bromide (MTT) assay. BV2 microglial cells were seeded in 96-well plates and treated with various concentrations of CA140 $(1-50 \mu \mathrm{M})$ or vehicle (1\% DMSO) for $24 \mathrm{~h}$ in the absence of FBS. The cells were subsequently treated with $0.5 \mathrm{mg} / \mathrm{mL}$ MTT and incubated for $3 \mathrm{~h}$ at $37{ }^{\circ} \mathrm{C}$ in a $5 \%$ $\mathrm{CO}_{2}$ incubator. The absorbance was read at $580 \mathrm{~nm}$.

\section{Reverse transcription-polymerase chain reaction (RT-PCR)} Total RNA was extracted from cells using TRIzol (Invitrogen) following the manufacturer's instructions. Total RNA was reverse transcribed into cDNA using a Superscript cDNA Premix Kit II with oligoDT (GeNetBio, Korea), and RT-PCR was performed using Prime Taq Premix (GeNetBio, Korea). RT-PCR products were separated by electrophoresis on $1.5 \%$ agarose gels with Eco Dye (1:5000, Korea) and photographed. Images were analyzed using ImageJ (NIH) and Fusion (Korea).

\section{Immunocytochemistry}

BV2 microglial cells were fixed in ice-cold methanol for $8 \mathrm{~min}$, washed three times with $1 \times$ PBS, and incubated with CD11b and COX-2 or CD11b and IL- $1 \beta$ antibodies in GDB buffer $(0.1 \%$ gelatin, $0.3 \%$ Triton $\mathrm{X}-100,16 \mathrm{mM}$ sodium phosphate $\mathrm{pH} 7.4$, and $450 \mathrm{mM} \mathrm{NaCl}$ ) overnight at $4{ }^{\circ} \mathrm{C}$. The next day, the cells were washed three times with $1 \times$ PBS and incubated with the following secondary antibodies for $1 \mathrm{~h}$ at room temperature: Alexa Fluor 488 and Alexa Fluor 555 (1:200, Molecular Probes, USA). Images were obtained on a single plane using a confocal microscope (Nikon, Japan) and analyzed using ImageJ software.

\section{Immunohistochemistry and immunofluorescence}

Animals were perfused and fixed with $4 \%$ paraformaldehyde (PFA) solution, and brain tissues were flash-frozen and dissected using a cryostat (35-mm-thick sections). Each brain section was processed for immunofluorescence or immunohistochemical staining. For immunofluorescence staining, sections were rinsed in PBS and incubated with rabbit anti-Iba-1 (1:1000, Wako, Japan) for microglia or rabbit anti-GFAP (1:5000, Neuromics) for astrocytes. Antibodies were diluted in $0.5 \%$ bovine serum albumin (BSA) and incubated at $4{ }^{\circ} \mathrm{C}$ overnight. The following day, tissues were rinsed with $0.5 \%$ BSA and incubated with Alexa Fluor 555-conjugated anti-rabbit IgG (1:200, Molecular Probes) for $1 \mathrm{~h}$ at room temperature. The tissues were subsequently mounted on a gelatin-coated cover glass and covered with DAPI-containing mounting solution (Vector Laboratories). Images of the stained tissues were captured using confocal microscopy (TI-RCP, Nikon).

For immunohistochemistry, sections were permeabilized for $1 \mathrm{~h}$ in PBS with $0.2 \%$ Triton X-100 and $1 \%$ BSA at room temperature. The sections were then incubated with primary antibodies at $4{ }^{\circ} \mathrm{C}$ overnight. The next day, the tissues were washed three times with $0.5 \%$ BSA and incubated with biotin-conjugated anti-rabbit antibody (1:400, Vector Laboratories) for $1 \mathrm{~h}$ at room temperature. After rinsing with $0.5 \% \mathrm{BSA}$, the sections were incubated for $1 \mathrm{~h}$ at room temperature in avidin-biotin complex solution (Vector Laboratories, Burlingame, CA), followed by rinsing three times in $0.1 \mathrm{M}$ phosphate buffer (PB). The signal was detected by incubating the sections in $0.5 \mathrm{mg} / \mathrm{mL} \mathrm{3,3}$ '-diaminobenzidine (DAB, Sigma-Aldrich) in $0.1 \mathrm{M} \mathrm{PB}$ containing $0.003 \% \mathrm{H}_{2} \mathrm{O}_{2}$. The sections were rinsed in $0.1 \mathrm{M} \mathrm{PB}$ and mounted on gelatin-coated slides, and images were obtained under a bright-field microscope (Leica).

\section{Enzyme-linked immunosorbent assay (ELISA)}

To measure the effects of pre- or post-treatment with CA140 on IL-1 $\beta$, an enzyme-linked immunosorbent assay (ELISA) was performed. Briefly, BV2 microglial cells were treated with LPS $(100 \mathrm{ng} / \mathrm{mL})$ or PBS for $30 \mathrm{~min}$, followed by treatment with CA140 $(10 \mu \mathrm{M})$ or vehicle (1\% DMSO). IL-1 $\beta$ ELISA was then performed using the conditioned medium. Mouse IL-1 $\beta$ ELISA kits (ELISA development reagents; R\&D Systems, Minneapolis, MN) were used according to the manufacturer's recommendations. Recombinant mouse IL-1 $\beta$ protein 
(R\&D Systems) was used as a standard. The absorbance of the samples was measured at $450 \mathrm{~nm}$ using a microplate reader (BMG Labtech, Offenburg, Germany).

\section{Griess assay}

To examine the effects of CA140 on nitrite (NO) production, the Griess assay was performed. BV2 microglial cells were incubated with CA140 $(10 \mu \mathrm{M})$ or vehicle $(1 \%$ DMSO) for $30 \mathrm{~min}$, followed by treatment with LPS $(100 \mathrm{ng} / \mathrm{mL})$ or PBS for $23.5 \mathrm{~h}$. The conditioned medium was mixed with Griess reagent $(0.1 \%$ $N$-(1-naphthyl)ethylenediamine dihydrochloride and 1\% sulfanilamide in $2 \%$ phosphoric acid) in 96-well plates and incubated at room temperature for $5 \mathrm{~min}$. The absorbance was measured at $540 \mathrm{~nm}$ using a microplate reader, and the level of nitrite was analyzed against a standard curve of sodium nitrite.

\section{Western blotting}

Cells were lysed using RIPA buffer containing protease and phosphatase inhibitor tablets (Roche, USA). Western blot analysis was performed as previously described [22]. Images were analyzed using Fusion software or ImageJ.

\section{Cytosolic and nuclear fractionation}

BV2 microglial cells were lysed in cytosolic fractionation buffer (10 mM HEPES pH 8.0, $1.5 \mathrm{mM} \mathrm{MgCl}_{2}, 10 \mathrm{mM}$ $\mathrm{KCl}, 0.5 \mathrm{mM}$ DTT, $300 \mathrm{mM}$ sucrose, $0.1 \% \mathrm{NP}-40$, and $0.5 \mathrm{mM}$ PMSF). After $5 \mathrm{~min}$, the cell lysates were centrifuged at $10,000 \mathrm{rpm}$ at $4{ }^{\circ} \mathrm{C}$ for $1 \mathrm{~min}$, and the supernatant was stored as the cytosolic fraction. The pellet was lysed in nuclear fractionation buffer (10 mM HEPES $\mathrm{pH}$ 8.0, $20 \%$ glycerol, $100 \mathrm{mM} \mathrm{KCl}, 100 \mathrm{mM} \mathrm{NaCl}$, $0.2 \mathrm{mM}$ EDTA, $0.5 \mathrm{mM}$ DTT, and $0.5 \mathrm{mM}$ PMSF) on ice for $15 \mathrm{~min}$, followed by centrifugation at 10,000 rpm at $4{ }^{\circ} \mathrm{C}$ for $15 \mathrm{~min}$. The cytosolic and nuclear fractions were analyzed by western blot as previously described [23].

\section{Statistical analyses}

All data were analyzed using a two-tailed $T$ test or ANOVA with GraphPad Prism 4 software. Post hoc analyses were performed using Tukey's multiple comparison test with significance set at $p<0.05$. Data are presented as the mean \pm S.E.M. $\left({ }^{*} p<0.05,{ }^{* * *} p<0.01,{ }^{* * * *} p<0.001\right)$.

\section{Results}

\section{CA140 has no cytotoxicity in BV2 microglial cells up to $25 \mu \mathrm{M}$}

We recently synthesized CA140 formally by benzoylation of dopamine (DA) with $\mathrm{N}$-Methylisatoic anhydride (Fig. 1a) and examined whether the newly developed CA140 crosses the blood-brain barrier. In a pharmacokinetic study, we determined that the relevant brain-to-plasma ratio was $1.91 \pm 0.22$ (brain concentration, $2310-4457 \mathrm{ng} / \mathrm{mL}$ ), which indicates a high brain distribution of CA140 (data not shown). In addition, we measured the stability of CA140 in vitro and found that the rates of disappearance of CA140 and DA (as a control for CA140) were comparable within the first $8 \mathrm{~h}$. However, after $22 \mathrm{~h}$, more than $40 \%$ of CA140 remained in solution, whereas DA was no longer detectable (Fig. 1b).

To examine the effects of CA140 on the LPS-induced neuroinflammatory response, we initially assessed the cytotoxicity of CA140 in BV2 microglial cells. BV2 microglial cells were treated with vehicle (1\% DMSO) or CA140 $(1,5,10,25$, or $50 \mu \mathrm{M})$ for $24 \mathrm{~h}$, and MTT assays were performed. CA140 did not affect cell viability up to a concentration of $25 \mu \mathrm{M}$; however, CA140 exhibited some toxicity at $50 \mu \mathrm{M}$ in BV2 microglial cells (Fig. 1c).

We then assessed whether CA140 can alter cell morphology in LPS-stimulated BV2 microglial cells. BV2 microglial cells were pretreated with LPS $(1 \mu \mathrm{g} / \mathrm{mL})$ or PBS for $30 \mathrm{~min}$ and treated with vehicle (1\% DMSO) or CA140 $(10 \mu \mathrm{M})$ for $5.5 \mathrm{~h}$. After $6 \mathrm{~h}, \mathrm{BV} 2$ microglial cells were fixed and immunostained with anti-CD11b and anti-F-actin antibodies. LPS treatment produced aberrant cell morphology of BV2 microglial cells, such as thin fibroblast-like processes from the cell body (Fig. 1d, middle panel). However, treatment with LPS followed by CA140 appeared to rescue this abnormal cell morphology (Fig. 1d, lower panel).

\section{CA140 reduces proinflammatory cytokine levels in LPS- stimulated BV2 microglial cells}

To determine whether post-treatment with CA140 reduces proinflammatory responses in LPS-stimulated BV2 microglial cells, cells were pretreated with LPS $(1 \mu \mathrm{g} / \mathrm{mL})$ or PBS for $30 \mathrm{~min}$, followed by treatment with CA140 (5 or $10 \mu \mathrm{M})$ or vehicle (1\% DMSO) for $5.5 \mathrm{~h}$. Proinflammatory cytokine levels were then measured by RT-PCR. Interestingly, we observed that $5 \mu \mathrm{M}$ CA140 only significantly decreased LPS-induced IL-1 $\beta$ mRNA levels (Additional file 1: Figure S1a-g). To determine if post-treatment with a higher concentration of CA140 could alter LPS-stimulated increase in proinflammatory cytokine levels, BV2 microglial cells were subjected to the same procedure but with $10 \mu \mathrm{M}$ CA140, and proinflammatory cytokine levels were measured by RT-PCR. Post-treatment with $10 \mu \mathrm{M}$ CA140 significantly reduced LPS-induced IL- $1 \beta$ and COX-2 mRNA levels in BV2 microglial cells (Fig. 2a-g). As a complementary study, BV2 microglial cells were treated with LPS $(1 \mu \mathrm{g} / \mathrm{mL})$ or PBS for $30 \mathrm{~min}$, followed by treatment with vehicle (1\% DMSO) or CA140 $(10 \mu \mathrm{M})$ for $5.5 \mathrm{~h}$ and analysis by immunocytochemistry. Consistent with our findings above, 
a

CA140<smiles>CNc1ccccc1C(=O)NCCc1ccc(O)c(O)c1</smiles>

b
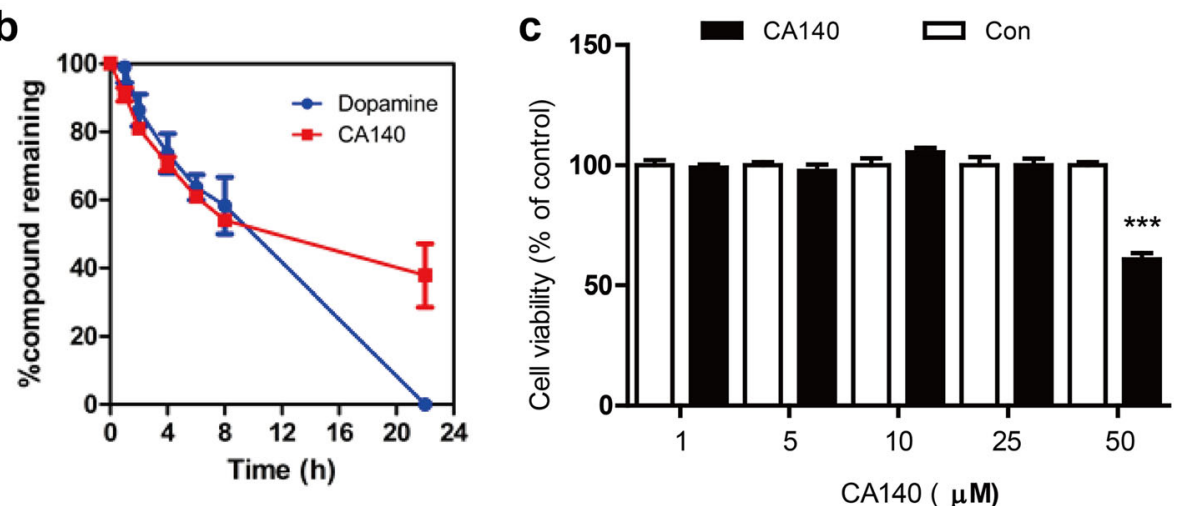

d

Enlarge
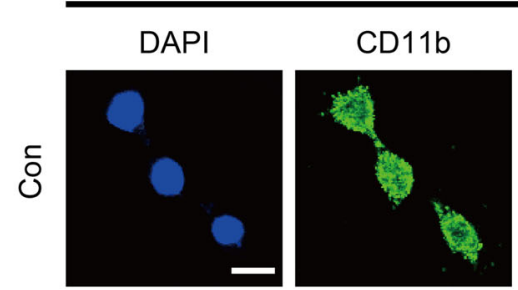

F-actin

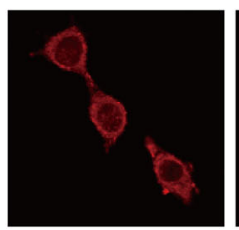

Merge
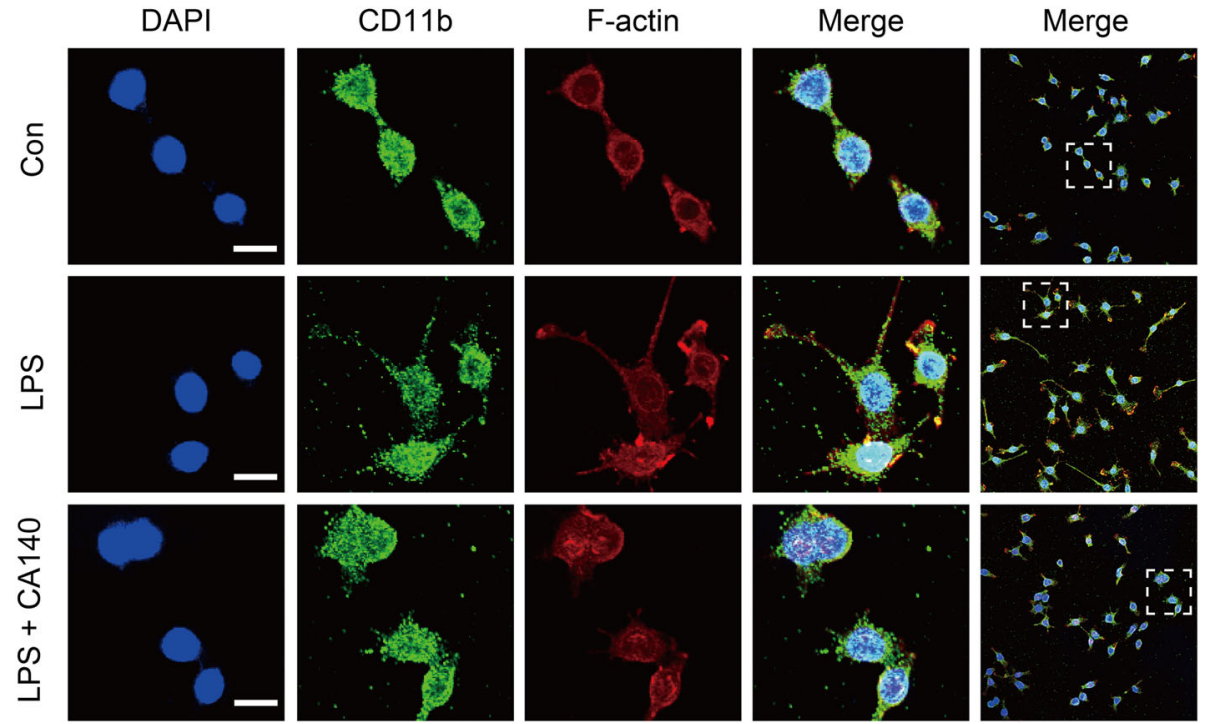

Fig. 1 Concentrations of CA140 up to $25 \mu \mathrm{M}$ were not toxic in BV2 microglial cells. a Structure of CA140. b Stability studies of CA140 and dopamine (DA) in vitro. c BV2 microglial cells were treated with vehicle (1\% DMSO) or CA140 at various concentrations (1, 5, 10, 25, or 50 $\mu \mathrm{M})$ for $24 \mathrm{~h}$, and cell viability was measured ( $n=8$ for each dose). $\mathbf{d}$ BV2 microglial cells were pretreated with $\mathrm{LPS}(1 \mu \mathrm{g} / \mathrm{mL})$ or PBS for $30 \mathrm{~min}$, followed by treatment with vehicle (1\% DMSO) or CA140 $(10 \mu \mathrm{M})$ for $6 \mathrm{~h}$ and immunostaining with anti-CD11 b and anti-F-actin antibodies. ${ }^{* * *} p<0.001$

post-treatment with CA140 also significantly reduced the levels of COX-2 and IL- $1 \beta$ in LPS-stimulated BV2 microglial cells (Fig. 2h-k). To further confirm these findings, we conducted an IL-1 $\beta$ ELISA assay. For this experiment, BV2 microglial cells were pretreated with LPS $(100 \mathrm{ng} / \mathrm{mL})$ or PBS for $30 \mathrm{~min}$, followed by treatment with CA140 $(10 \mu \mathrm{M})$ or vehicle $(1 \%$ DMSO) for $23.5 \mathrm{~h}$. The IL-1 $\beta$ ELISA assay was then performed. Consistent with the findings above, post-treatment with CA140 significantly decreased LPS-induced IL-1 $\beta$ levels compared with LPS treatment alone (Fig. 2l).

We then examined whether post-treatment with CA140 can further regulate LPS-induced proinflammatory cytokine levels in a longer treatment. BV2 microglial cells were pretreated with LPS $(1 \mu \mathrm{g} / \mathrm{mL})$ or PBS for $30 \mathrm{~min}$, followed by treatment with CA140 $(10 \mu \mathrm{M})$ or vehicle ( $1 \%$ DMSO) for 11.5 or $23.5 \mathrm{~h}$. 


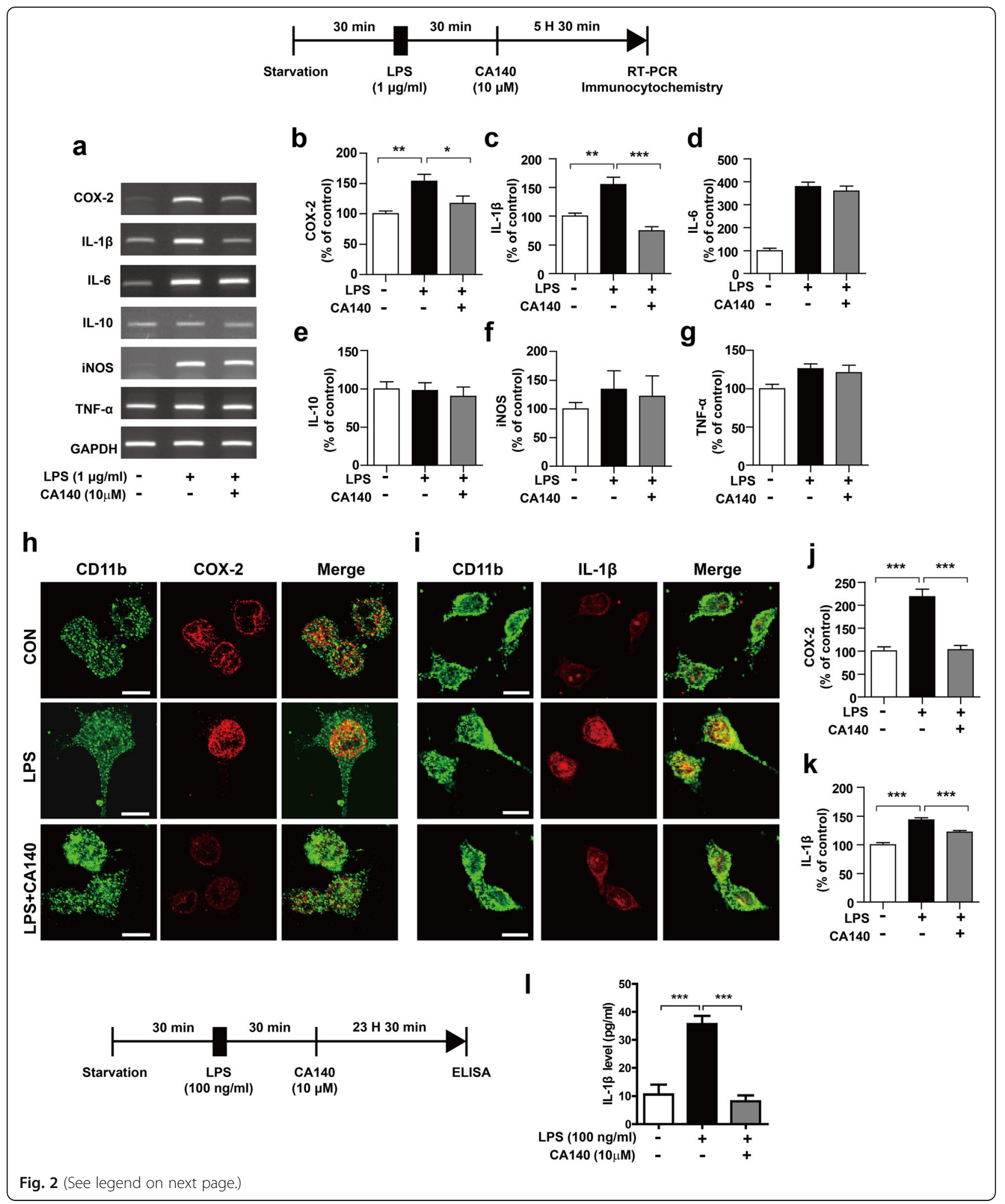




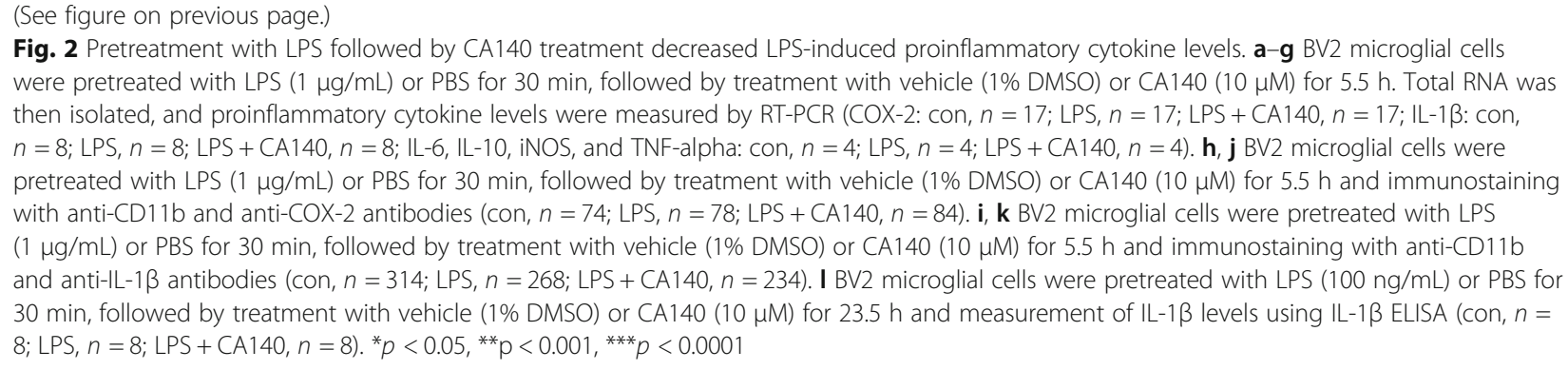

Proinflammatory cytokine levels were then measured by RT-PCR. Interestingly, post-treatment with CA140 significantly suppressed LPS-induced proinflammatory cytokine levels in a time-dependent manner (Additional file 1: Figure S2a-1).

We subsequently examined whether pretreatment with CA140 prevents LPS-induced neuroinflammatory responses. BV2 microglial cells were incubated with CA140 $(5 \mu \mathrm{M})$ or vehicle (1\% DMSO) for $30 \mathrm{~min}$, followed by LPS $(1 \mu \mathrm{g} / \mathrm{mL})$ or PBS for $5.5 \mathrm{~h}$. Proinflammatory cytokine levels were evaluated by RT-PCR. Pretreatment with $5 \mu \mathrm{M}$ CA140 followed by LPS treatment did not decrease proinflammatory cytokine levels (Additional file 1: Figure S3a-g). However, pretreatment with $10 \mu \mathrm{M}$ CA140 significantly reduced the mRNA levels of COX-2, IL-1 $\beta$, and iNOS (Additional file 1: Figure $\mathrm{S} 3 \mathrm{~h}-\mathrm{n}$ ). In addition, pretreatment with $\mathrm{CA} 140$ at $10 \mu \mathrm{M}$ significantly decreased LPS-induced IL-1 $\beta$ and NO levels as assessed by IL-1 $\beta$ ELISA or the Griess assay (Additional file 1: Figure S3o-p).

We then investigated whether pretreatment with CA140 further regulates LPS-induced proinflammatory cytokine levels in a longer treatment. BV2 microglial cells were incubated with CA140 $(10 \mu \mathrm{M})$ or vehicle (1\% DMSO) for $30 \mathrm{~min}$, followed by LPS $(1 \mu \mathrm{g} / \mathrm{mL})$ or PBS for 11.5 or $23.5 \mathrm{~h}$. Longer pretreatment with CA140 further reduced LPS-induced mRNA levels of the proinflammatory cytokines COX-2, IL-1 $\beta$, and iNOS compared with pretreatment for $6 \mathrm{~h}$ (Additional file 1: Figure S4a-h). These results suggest that CA140 both reduces and prevents proinflammatory responses in LPS-induced BV2 microglial cells. Based on these findings, we selected $10 \mu \mathrm{M}$ CA140 as our optimal working concentration for further experiments.

\section{CA140 reduces LPS-induced proinflammatory cytokine} levels in primary microglial cells and primary astrocytes Although BV2 microglial cells have been extensively used as an alternative model system for investigating microglial function in neuroinflammation [24], we aimed to examine whether pre- or post-treatment with CA140 modulates proinflammatory responses in different cell types, such as primary microglial cells or primary astrocytes. For these experiments, rat primary microglial or primary astrocyte cultures in high-glucose DMEM were used. Rat primary microglial cells were treated with LPS $(1 \mu \mathrm{g} / \mathrm{mL})$ or PBS for $30 \mathrm{~min}$, followed by vehicle $(1 \%$ DMSO) or CA140 $(10 \mu \mathrm{M})$ for $5.5 \mathrm{~h}$. Proinflammatory cytokine levels were measured by RT-PCR. Post-treatment with CA140 significantly decreased the mRNA levels of COX-2 and IL- $1 \beta$ in LPS-stimulated rat primary microglial cells (Additional file 1: Figure S5a-f) but failed to lower proinflammatory cytokine levels in LPS-induced rat primary astrocytes (Additional file 1: Figure S5g-l).

We subsequently examined whether pretreatment with CA140 differentially regulates LPS-induced proinflammatory responses in rat primary microglial cells and primary astrocytes. Rat primary microglial cells or primary astrocytes were pretreated with CA140 $(10 \mu \mathrm{M})$ or vehicle (1\% DMSO) for $30 \mathrm{~min}$, followed by treatment with LPS $(1 \mu \mathrm{g} / \mathrm{mL})$ or PBS for $5.5 \mathrm{~h}$. Proinflammatory cytokine levels were then measured by RT-PCR. Interestingly, pretreatment with CA140 reduced LPS-induced COX-2, IL-1 $\beta$, iNOS, and TNF- $\alpha$ mRNA levels in rat primary microglial cells (Additional file 1: Figure S6a-f). In addition, pretreatment with CA140 significantly decreased the mRNA levels of IL- 6 and iNOS in rat primary astrocytes (Additional file 1: Figure S6g-l).

Several recent studies have demonstrated that primary glial cells can be activated by high glucose levels [25-28]. Thus, we cultured primary glial cells under low-glucose DMEM conditions to test whether pre-or post-treatment with CA140 can differentially affect LPS-induced neuroinflammatory responses under low-glucose conditions. Mouse primary microglial cells were treated with LPS $(1 \mu \mathrm{g} / \mathrm{mL})$ or PBS for $30 \mathrm{~min}$, followed by vehicle $(1 \%$ DMSO) or CA140 $(10 \mu \mathrm{M})$ for $5.5 \mathrm{~h}$, and proinflammatory cytokine levels were measured by RT-PCR. Post-treatment with CA140 significantly reduced IL-6, iNOS, and TNF-alpha mRNA levels in LPS-stimulated mouse primary microglial cells (Fig. 3a-f). Interestingly, post-treatment with CA140 significantly suppressed LPS-stimulated iNOS mRNA levels in primary astrocytes but not the levels of other proinflammatory cytokines 


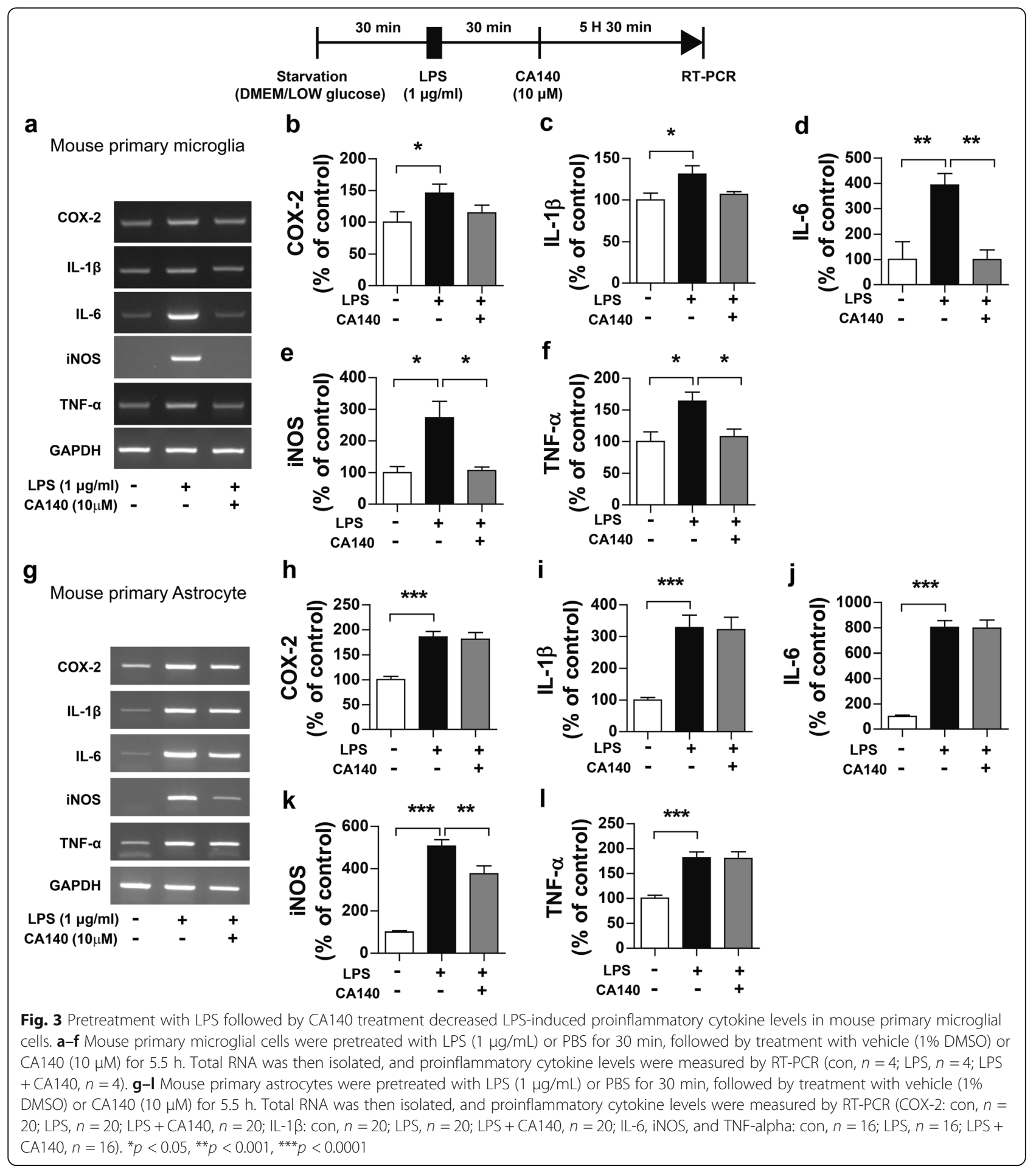

(Fig. 3g-1). In addition, pretreatment with CA140 significantly decreased LPS-induced proinflammatory cytokine levels in mouse primary microglial cells and primary astrocytes (Additional file 1: Figure S7a-1). These results indicate that the timing of CA140 treatment and culture conditions (high vs low glucose) can differentially affect the LPS-induced proinflammatory response depending on cell type. The alleviatory effect of CA140 was specific to microglial cells.

CA140 regulates the dopamine D1 receptor to alter proinflammatory cytokine levels

Because CA140 is structurally related to DA, we hypothesized that CA140 may directly or indirectly interact 
with DA receptors (i.e., D1R, D2R) to alter the neuroinflammatory response. To test this idea, we initially investigated whether BV2 microglial cells present endogenous dopamine D1 receptor (D1R) or dopamine D2 receptor (D2R). For the initial experiment, BV2 microglial cells were pretreated with LPS $(1 \mu \mathrm{g} / \mathrm{mL})$ or PBS for $30 \mathrm{~min}$, followed by treatment with CA140 $(10 \mu \mathrm{M})$ or vehicle (1\% DMSO) for $5.5 \mathrm{~h}$, and the mRNA levels of D1R were measured by RT-PCR. Interestingly, LPS treatment significantly increased D1R mRNA levels, whereas treatment with LPS followed by CA140 significantly downregulated D1R mRNA levels (Additional file 1: Figure S8a-b). To further confirm these findings, we performed immunocytochemistry with anti-CD11b and anti-D1R antibodies and determined that post-treatment with CA140 reduced D1R levels compared with LPS treatment (Additional file 1: Figure S8c, d).

We subsequently examined whether post-treatment with CA140 can alter D2R levels. BV2 microglial cells were pretreated with LPS $(1 \mu \mathrm{g} / \mathrm{mL})$ or PBS for $30 \mathrm{~min}$, followed by treatment with CA140 $(10 \mu \mathrm{M})$ or vehicle $(1 \%$ DMSO) for $5.5 \mathrm{~h}$ and immunocytochemistry with anti-CD11b and anti-D2R antibodies. Interestingly, LPS treatment significantly increased D2R levels in BV2 microglial cells (Additional file 1: Figure S8e, f). However, post-treatment with CA140 did not alter D2R levels compared with LPS treatment (Additional file 1: Figure S8e, f), which suggests that CA140 modulates only LPS-induced D1R expression levels in BV2 microglial cells.

To examine whether D1R or D2R affects the LPS-stimulated proinflammatory response, BV2 microglial cells were treated with LPS $(1 \mu \mathrm{g} / \mathrm{mL})$ or PBS for $30 \mathrm{~min}$, followed by treatment with a D1R antagonist (LE300, $10 \mu \mathrm{M})$ or vehicle (1\% DMSO) for $5.5 \mathrm{~h}$. Proinflammatory cytokine levels were then measured by RT-PCR. LE300 treatment significantly reduced LPS-stimulated COX-2 and IL-1 $\beta$ mRNA levels (Fig. 4a$\mathrm{f})$, which suggests that inhibition of D1R regulates the proinflammatory response in LPS-induced BV2 microglial cells.

Next, to investigate whether CA140 further regulates the neuroinflammatory response in the presence of a D1R antagonist, BV2 microglial cells were pretreated with LPS $(1 \mu \mathrm{g} / \mathrm{mL})$ or PBS for $30 \mathrm{~min}$, followed by treatment with LE300 (a D1R antagonist, $10 \mu \mathrm{M}$ ) or vehicle (1\% DMSO) for $30 \mathrm{~min}$ and finally CA140 $(10 \mu \mathrm{M})$ or vehicle (1\% DMSO) for $5 \mathrm{~h}$. Subsequent RT-PCR analysis revealed that treatment with LE300, CA140, and LPS further inhibited IL- $1 \beta$ mRNA levels compared with treatment with LE300 and LPS or CA140 and LPS (Fig. 4g-h).

To further confirm these findings, BV2 microglial cells were treated with LPS $(1 \mu \mathrm{g} / \mathrm{mL})$ or PBS for $30 \mathrm{~min}$, followed by another D1R antagonist (SCH23390, $30 \mu \mathrm{M})$ or vehicle (1\% DMSO) for $5.5 \mathrm{~h}$, and proinflammatory cytokine levels were measured by RT-PCR. SCH23390 treatment significantly decreased LPS-induced COX-2 and IL-1 $\beta$ mRNA levels (Fig. $4 \mathrm{i}-\mathrm{n}$ ). In addition, treatment with SCH23390, CA140, and LPS further inhibited LPS-stimulated COX-2 and IL-1 $\beta$ mRNA levels compared with treatment with LPS and SCH23390 (Fig. 4o-p).

Next, to examine whether D1R agonist treatment alters neuroinflammatory responses, BV2 microglial cells were treated with LPS $(1 \mu \mathrm{g} / \mathrm{mL})$ or PBS for $30 \mathrm{~min}$, followed by a D1R agonist (A77636, $10 \mathrm{nM}$ ) or PBS for $5.5 \mathrm{~h}$ and measurement of proinflammatory cytokine levels by RT-PCR. A77636 treatment did not decrease any LPS-induced proinflammatory cytokine levels (Fig. 5a-f).

We then investigated whether CA140 modulates neuroinflammatory responses in the presence of a D1R agonist. BV2 microglial cells were pretreated with LPS $(1 \mu \mathrm{g} / \mathrm{mL})$ or PBS for $30 \mathrm{~min}$, followed by treatment with A77636 (a D1R agonist, $10 \mathrm{nM}$ ) or PBS for $30 \mathrm{~min}$ and finally CA140 $(10 \mu \mathrm{M})$ or vehicle (1\% DMSO) for $5 \mathrm{~h}$; we subsequently performed RT-PCR. Consistent with our findings above, post-treatment with CA140 dramatically reduced LPS-induced IL- $1 \beta$ mRNA levels (Fig. 5g-h). Most importantly, treatment with LPS, A77636, and CA140 significantly reduced LPS-induced IL-1 $\beta$ mRNA levels compared with treatment with A77636 and LPS (Fig. 5g-h).

We subsequently examined whether D2R inhibition affects the proinflammatory response in LPS-induced BV2 microglial cells and found that treatment with D2R antagonist did not suppress LPS-induced proinflammatory cytokine levels (Additional file 1: Figure S9a-f). In addition, treatment with LPS, EH, and CA140 did not decrease LPS-induced IL-1 $\beta$ mRNA levels compared with treatment with EH and LPS or CA140 and LPS (Additional file 1: Figure S9g-h). Taken together, these results suggest that CA140 may modulate D1R to alter proinflammatory responses.

\section{CA140 alters LPS-induced ERK signaling in BV2 microglial cells}

Several studies have shown that ERK and AKT signaling plays an important role in regulating proinflammatory cytokines in microglial cells [29]. Thus, we investigated whether pre- or post-treatment with CA140 regulates ERK and AKT signaling to alter the LPS-induced neuroinflammatory response. BV2 microglial cells were pretreated with LPS $(1 \mu \mathrm{g} / \mathrm{mL})$ or PBS for $45 \mathrm{~min}$, followed by treatment with CA140 $(10 \mu \mathrm{M})$ or vehicle $(1 \%$ DMSO) for $45 \mathrm{~min}$ and western blotting with anti-p-ERK/ERK or anti-p-AKT/AKT antibodies. Post-treatment with CA140 did not significantly alter p-AKT levels (Fig. 6a-c), whereas post-treatment with 


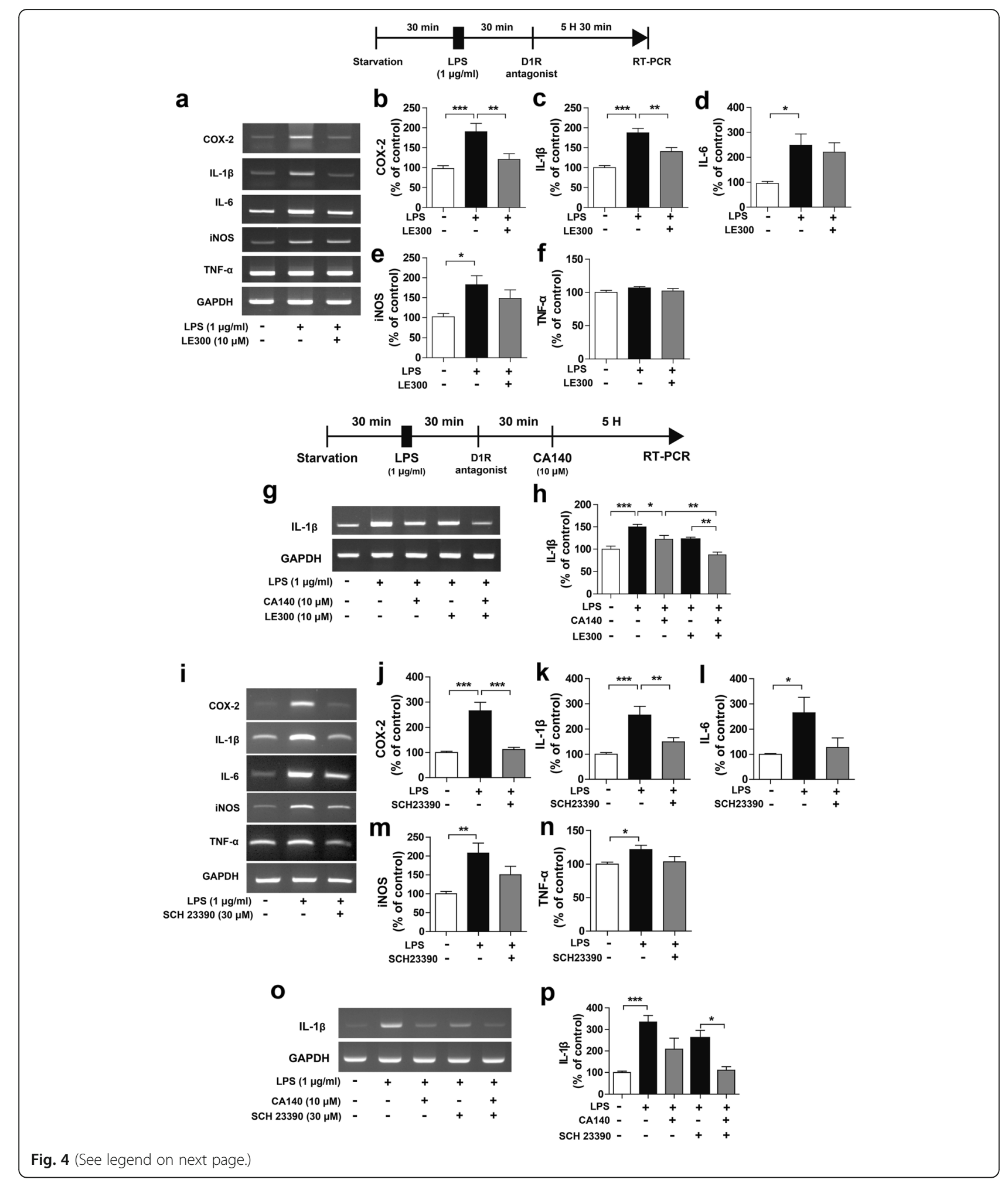




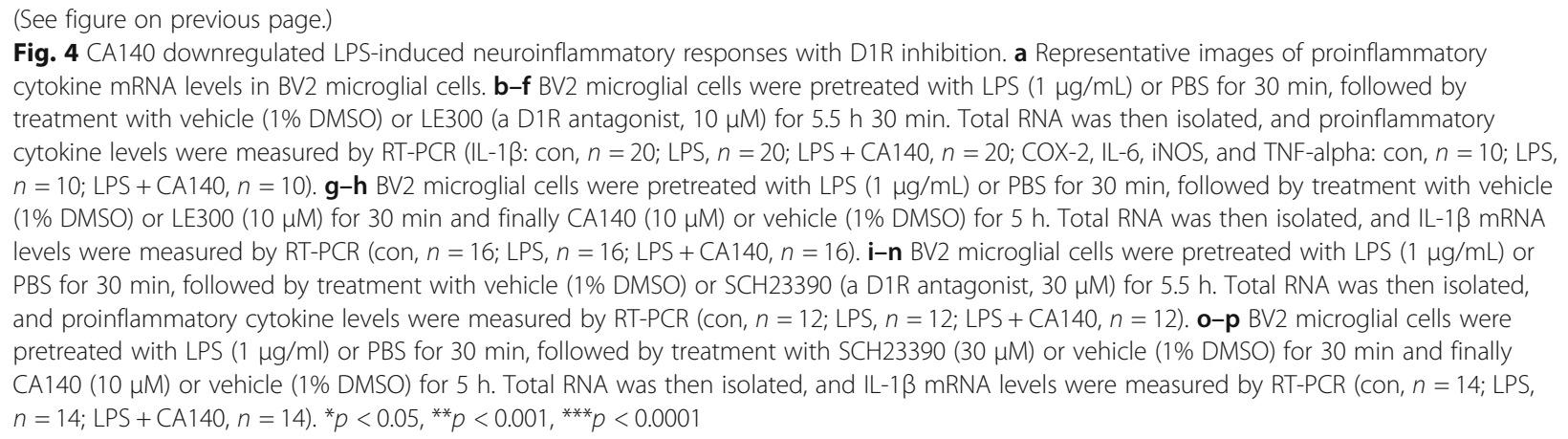

CA140 significantly decreased p-ERK levels in LPS-stimulated BV2 microglial cells (Fig. 6d-f).

We subsequently assessed whether post-treatment with CA140 regulates the LPS-stimulated proinflammatory response through ERK signaling. BV2 microglial cells were pretreated with LPS $(1 \mu \mathrm{g} / \mathrm{mL})$ or PBS for $30 \mathrm{~min}$, followed by treatment with PD98059 (an ERK inhibitor, $10 \mu \mathrm{M})$ or vehicle (1\% DMSO) for $30 \mathrm{~min}$ and finally vehicle $(1 \%$ DMSO) or CA140 $(10 \mu \mathrm{M})$ for $5 \mathrm{~h}$. The mRNA levels of COX-2 and IL-1 $\beta$ were measured by RT-PCR. Consistent with our previously described findings, post-treatment with CA140 significantly decreased the mRNA levels of COX-2 and IL-1 $\beta$ (Fig. 6gi). In addition, compared with LPS and PD98059 treatment, treatment with LPS, PD98059, and CA140 further decreased COX-2 and IL-1 $\beta$ mRNA levels (Fig. 6g-i).

We then examined whether pretreatment with CA140 alters ERK and AKT signaling. BV2 cells were pretreated with vehicle (1\% DMSO) or CA140 $(10 \mu \mathrm{M})$ for $45 \mathrm{~min}$, followed by LPS $(1 \mu \mathrm{g} / \mathrm{mL})$ or PBS treatment for $45 \mathrm{~min}$ and western blotting with anti-p-ERK/ERK or anti-p-AKT/ AKT antibodies. Interestingly, pretreatment with CA140 significantly suppressed the phosphorylation of ERK and AKT in LPS-treated BV2 microglial cells (Additional file 1: Figure S10a-f). These data suggest that pre- or post-treatment with CA140 differentially affects ERK and AKT signaling.

\section{CA140 suppresses LPS-induced cytosolic and nuclear $p$ - STAT3 in BV2 microglial cells}

STAT3 plays an important role in the regulation of proinflammatory cytokine levels induced by LPS [30]. Thus, we examined whether CA140 regulates STAT3 expression in the nucleus and cytosol. BV2 microglial cells were pretreated with LPS $(1 \mu \mathrm{g} / \mathrm{mL})$ or PBS for $30 \mathrm{~min}$, followed by treatment with vehicle (1\% DMSO) or CA140 $(10 \mu \mathrm{M})$ for $5.5 \mathrm{~h}$ and subcellular fractionation. LPS treatment significantly increased p-STAT3 (Ser727) levels in the cytosol and nucleus (Fig. $7 \mathrm{a}-\mathrm{d}$ ). In addition, post-treatment with CA140 significantly reduced LPS-induced cytosolic and nuclear p-STAT3 (Ser727) levels (Fig. 7a-d). As a complementary study, we conducted immunocytochemistry with anti-CD11b and anti-p-STAT3 (Ser727) antibodies and determined that post-treatment with CA140 significantly decreased LPS-induced p-STAT3 (Ser727) levels in the nucleus (Fig. 7e-f).

In addition, we investigated whether pretreatment with CA140 alters LPS-stimulated p-STAT3 levels in the cytosol and nucleus. For this experiment, BV2 microglial cells were pretreated with vehicle (1\% DMSO) or CA140 $(10 \mu \mathrm{M})$ for $30 \mathrm{~min}$, followed by treatment with LPS $(1 \mu \mathrm{g} / \mathrm{mL})$ or PBS for $5.5 \mathrm{~h}$ and subcellular fractionation. Pretreatment with CA140 also significantly decreased LPS-induced cytosolic and nuclear p-STAT3 (Ser727) levels (Additional file 1: Figure S11a-d).

We then examined whether CA140 further regulates the LPS-induced proinflammatory response in the presence of a STAT3 inhibitor. BV2 microglial cells were pretreated with LPS $(1 \mu \mathrm{g} / \mathrm{mL})$ or PBS for $30 \mathrm{~min}$, followed by treatment with S31-201 (a STAT3 inhibitor, $50 \mu \mathrm{M}$ ) or vehicle (1\% DMSO) for 30 min and finally vehicle (1\% DMSO) or CA140 $(10 \mu \mathrm{M})$ for $5 \mathrm{~h}$. The mRNA levels of COX-2 and IL-1 $\beta$ were then measured by RT-PCR. Compared with treatment with LPS and S3I-201 or with LPS and CA140, treatment with LPS, S3I-201, and CA140 further decreased IL- $1 \beta$ and COX-2 mRNA levels (Fig. 7g-i). These data suggest that CA140 modulates STAT3 signaling to regulate the LPS-stimulated neuroinflammatory response.

\section{CA140 significantly reduces the activation of microglia and astrocytes in LPS-injected wild-type mice}

Numerous studies have shown that activated microglia and astrocytes are involved in neuroinflammatory responses [31]. To examine whether post-treatment with CA140 alters microglial and astrocyte activation in vivo, wild-type mice were injected with LPS $(10 \mathrm{mg} / \mathrm{kg} / \mathrm{day}$, i.p.) or PBS, followed $30 \mathrm{~min}$ later by injection with CA140 $(30 \mathrm{mg} / \mathrm{kg}$, i.p., twice with an interval of $1 \mathrm{~h}$, followed $30 \mathrm{~min}$ later by a third injection) or vehicle (10\% DMSO), and immunohistochemistry was performed with anti-Iba-1 and anti-GFAP antibodies. As expected, LPS-injected wild-type mice exhibited 


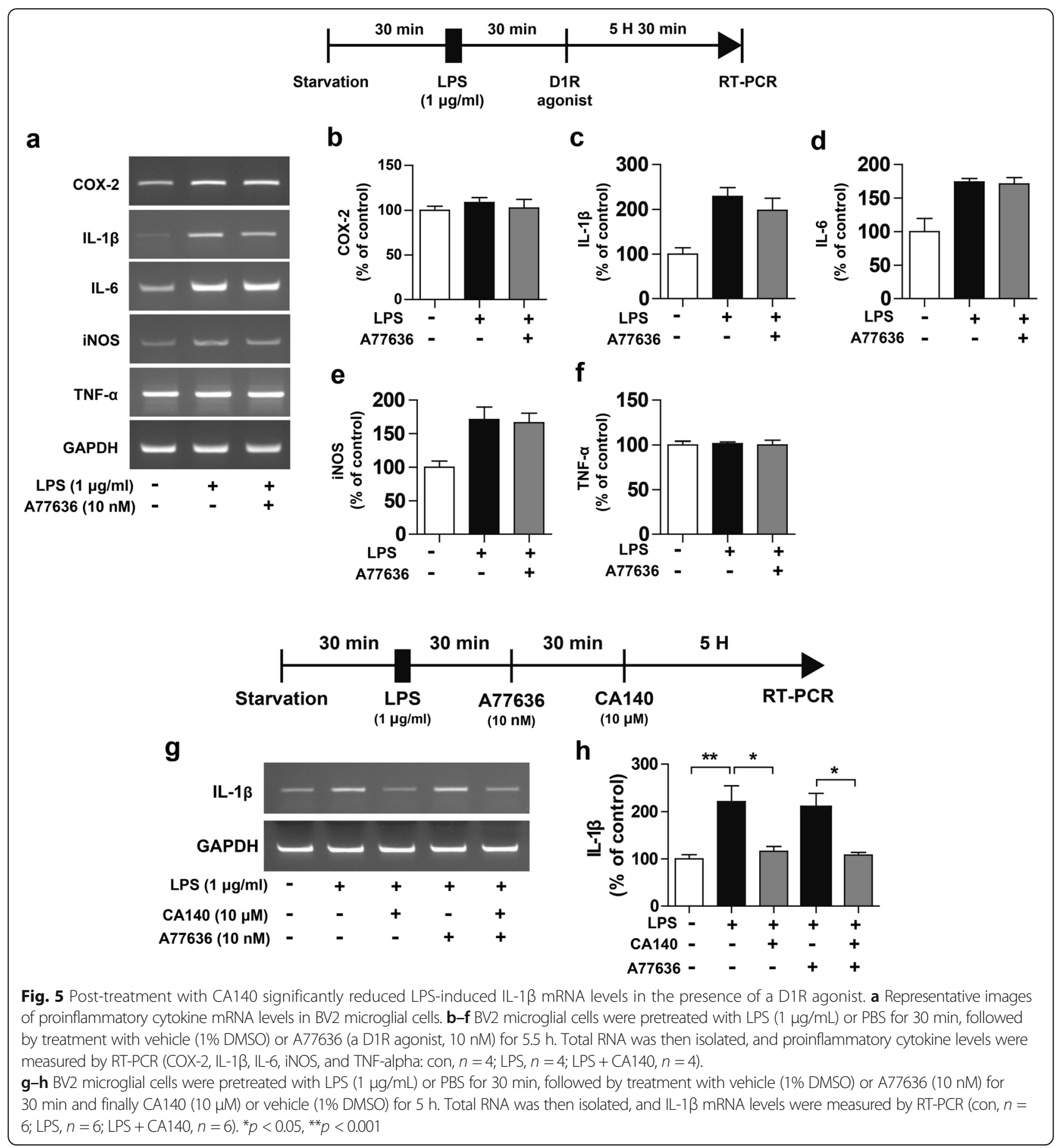

significantly increased Iba-1 (Fig. 8a-c) and GFAP (Fig. 8df) immunoreactivity in the hippocampus and cortex. In addition, post-treatment with CA140 significantly reduced microglial (Fig. 8a-c) and astrocyte (Fig. 8d-f) immunoreactivity compared with LPS-injected wild-type mice.

We subsequently examined whether post-treatment with CA140 alters LPS-stimulated proinflammatory cytokine levels in wild-type mice. For this experiment, wild-type mice were injected with LPS
$(10 \mathrm{mg} / \mathrm{kg} /$ day, i.p.) or PBS, followed $30 \mathrm{~min}$ later by injection with CA140 $(30 \mathrm{mg} / \mathrm{kg}$, i.p., twice with an interval of $1 \mathrm{~h}$, followed $30 \mathrm{~min}$ later by a third injection) or vehicle (10\% DMSO, i.p). Immunohistochemistry was performed with anti-IL-1 $\beta$ and anti-COX-2 antibodies. Post-treatment with CA140 significantly downregulated LPS-stimulated IL-1 $\beta$ (Fig. 9a-e) and COX-2 (Fig. 9f-h) immunoreactivity in the cortex and hippocampus. 


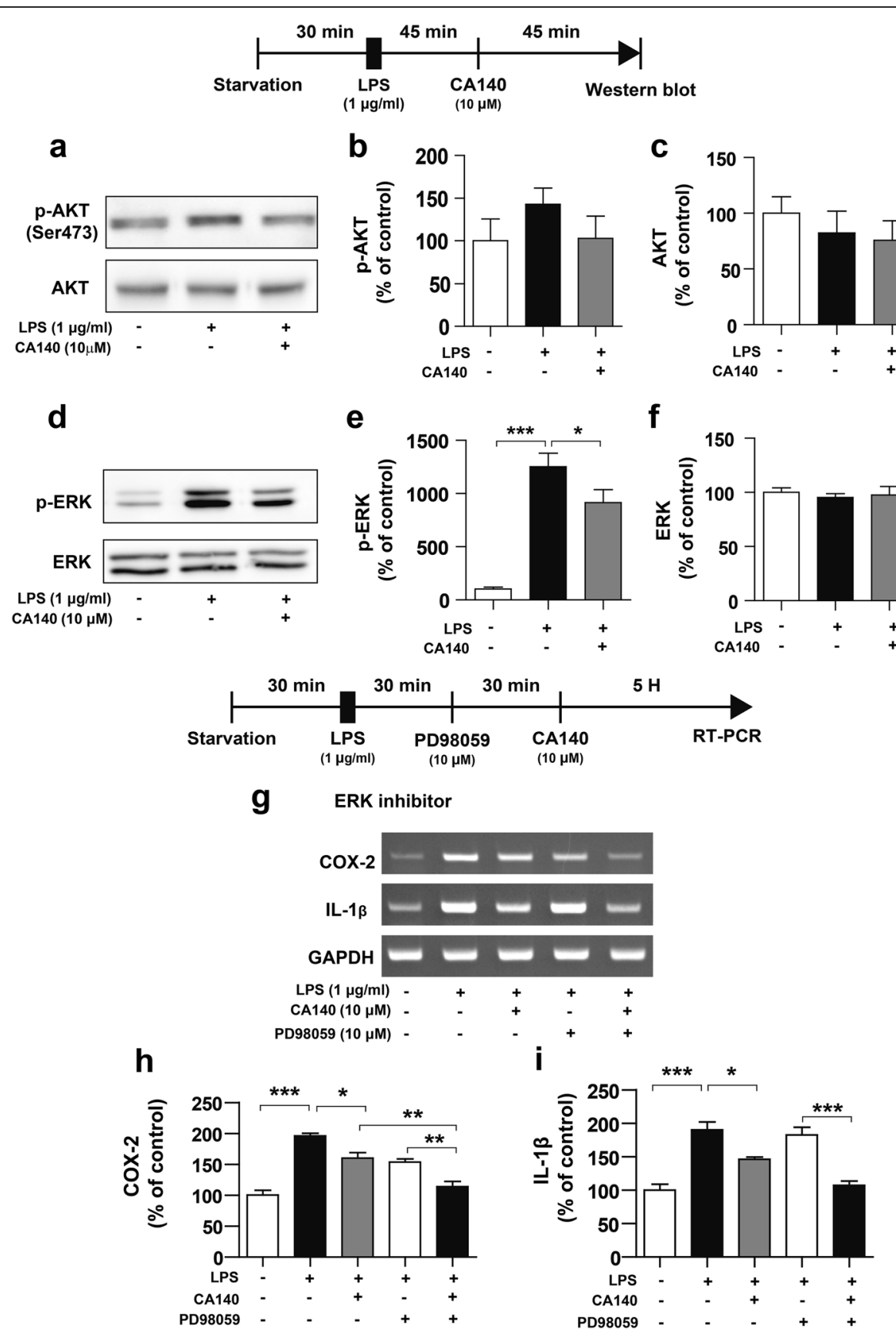

Fig. 6 Pretreatment with LPS followed by CA140 treatment decreased ERK signaling in LPS-stimulated BV2 cells. a-c BV2 microglial cells were pretreated with LPS $(1 \mu \mathrm{g} / \mathrm{mL})$ or PBS for $45 \mathrm{~min}$, followed by treatment with vehicle (1\% DMSO) or CA140 (10 $\mu \mathrm{M})$ for 45 min and western blotting with anti-p-AKT and anti-AKT antibodies ( $p$-AKT and AKT; con, $n=5 ;$ LPS, $n=5$; LPS + CA140, $n=5$ ). $\mathbf{d}-\mathbf{f}$ BV2 cells were pretreated with LPS $(1 \mu \mathrm{g} / \mathrm{ml})$ or PBS for $45 \mathrm{~min}$, followed by treatment with vehicle (1\% DMSO) or CA140 (10 $\mu \mathrm{M})$ for 45 min and western blotting with anti-pERK and anti-ERK antibodies (p-ERK and ERK; con, $n=6 ;$ LPS, $n=6$; LPS + CA140, $n=6$ ). g-i BV2 microglial cells were pretreated with LPS (1 $\mu \mathrm{g} /$ $\mathrm{mL}$ ) or PBS for $30 \mathrm{~min}$, followed by treatment with an ERK inhibitor (PD98059, $10 \mu \mathrm{M})$ or vehicle (1\% DMSO) for 30 min and finally CA140 (10 $\mu \mathrm{M})$ or vehicle (1\% DMSO) for $5 \mathrm{~h}$. Total RNA was then isolated, and IL-1 $\beta$ or COX-2 mRNA levels were measured by RT-PCR (COX-2 and IL-1 3 : Con, $n=4 ;$ LPS,$n=4 ;$ LPS + CA140, $n=4) .{ }^{*} p<0.05,{ }^{* *} p<0.001,{ }^{* * *} p<0.0001$ 


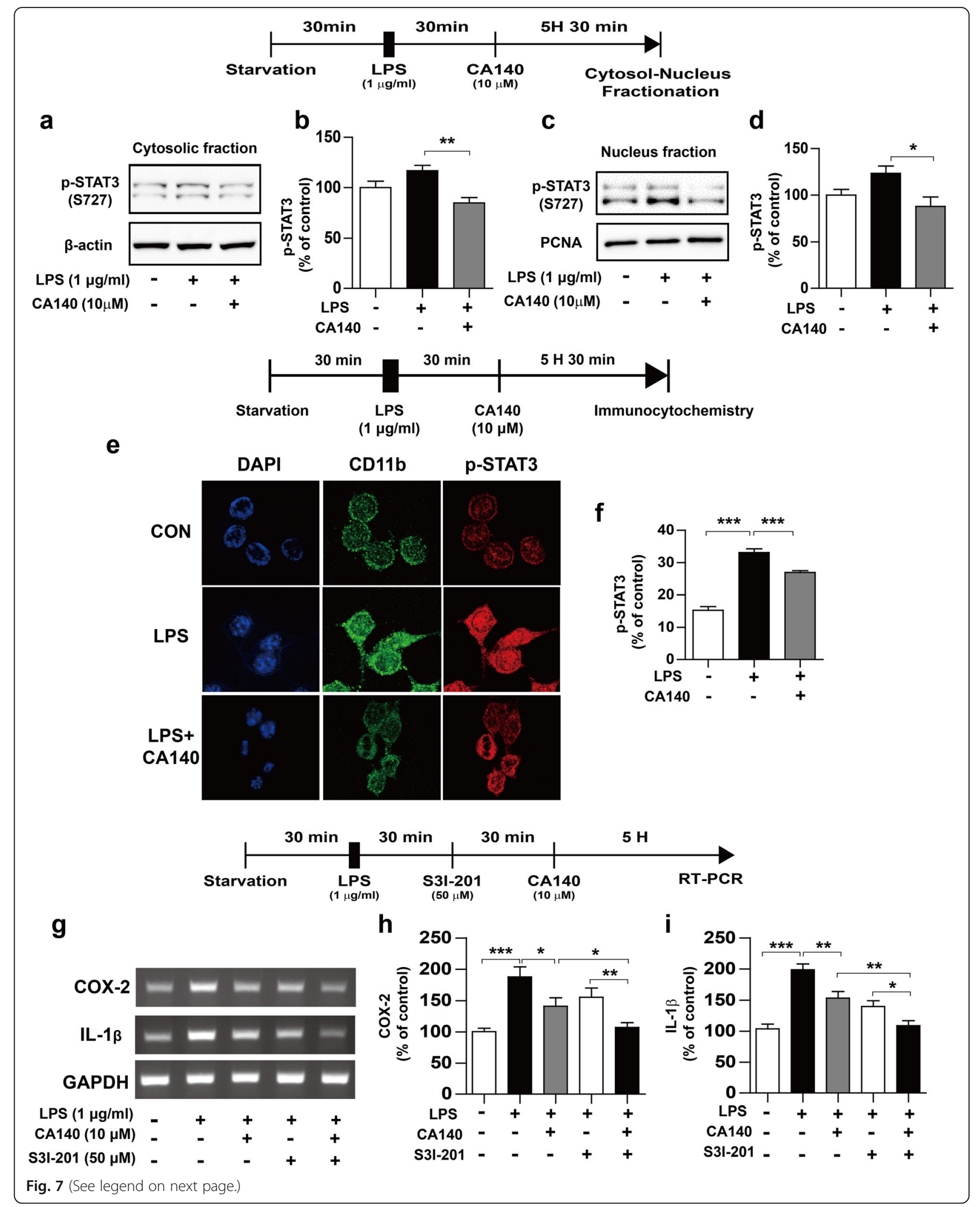




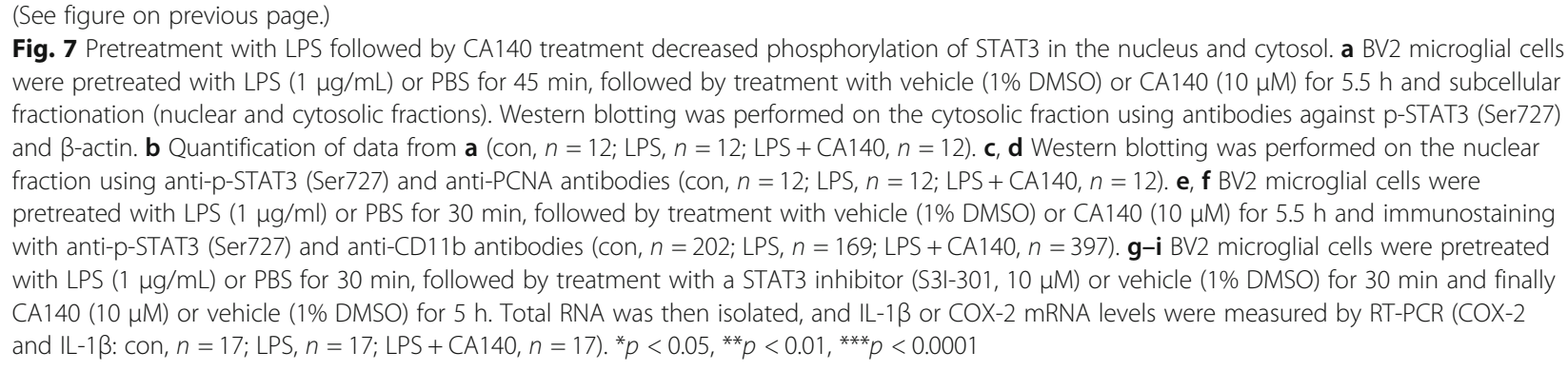

To further examine whether pretreatment with CA140 attenuates microglial and astrocyte activation, wild-type mice were injected with CA140 (30 mg/kg, i.p.) or vehicle (10\% DMSO, i.p.) daily for 3 days, followed by injection with LPS (10 mg/kg/day, i.p.) or PBS. Three hours later, immunohistochemistry was conducted with anti-Iba-1 and anti-GFAP antibodies. We observed that pretreatment with CA140 also significantly decreased microglial and astrocyte immunoreactivity (Additional file 1: Figure S12a-f). These results suggest that CA140 may be beneficial for the prevention and treatment of neuroinflammatory-related disease.

\section{CA140 significantly decreases the activation of microglia and astrocytes in a mouse model of AD}

Neuroinflammation and microglial activation are closely associated with neurodegenerative diseases, including AD [32-34]. Thus, we aimed to examine whether CA140 regulates microglial and astrocyte activation in a mouse model of AD. 5xFAD mice (3 months old) were injected with CA140 (30 mg/kg, i.p.) or vehicle $(10 \%$ DMSO, i.p.) daily for 2 weeks. After 2 weeks, immunohistochemistry was performed with anti-Iba-1 (a microglial cell marker, Fig. 10a-e) and anti-GFAP (an astrocyte marker, Fig. 10f-j) antibodies. CA140-injected 5xFAD mice had significantly reduced Iba-1 immunoreactivity in the hippocampus CA1 (Fig. 10a, b) and cortex (Fig. 10d, e) but not the dentate gyrus (Fig. 10a, c). Furthermore, CA140-injected 5xFAD mice had significantly suppressed GFAP immunoreactivity in the hippocampus DG (Fig. 10f, h) and cortex (Fig. 10i, j) but not the hippocampus CA1 (Fig. 10f, g). These data suggest that CA140 modulates microglial and astrocyte activation in a mouse model of AD.

\section{Discussion}

Increasing evidence is highlighting the critical role of the immune system in neurodegenerative diseases such as AD. Unchecked glial activation and neuroinflammation may represent hallmark diagnostic features of neurodegenerative diseases. However, research to explicate the mechanisms underlying neuroinflammation has been limited.
Several recent studies have demonstrated that microglia and astrocytes release proinflammatory cytokines, leading to neuronal cell death and synaptic dysfunction in neurodegenerative diseases, including $\operatorname{AD}[35,36]$. The release of these cytokines may be induced by LPS in vivo and in vitro via Toll-like receptors [37, 38]. McGeer et al. determined that neuroinflammation stimulated by a single intraperitoneal injection of LPS lasted 10 months in the mouse brain and eventually led to neurodegeneration. Therefore, the identification of agents that reduce proinflammatory cytokine levels may represent a promising strategy for developing drugs to treat neurodegenerative diseases.

In this study, we synthesized a novel analog of dopamine, CA140 that can penetrate the blood-brain barrier. We determined that $10 \mu \mathrm{M}$ CA140 was effective for lowering LPS-induced proinflammatory cytokine levels in BV2 microglial cells regardless of the timing of treatment (Fig. 2, Additional file 1: Figure S1). However, post-treatment with $5 \mu \mathrm{M}$ CA140 only reduced the mRNA levels of LPS-induced IL-1 $\beta$ and not those of other proinflammatory cytokines. Our findings imply that an appropriate concentration of CA140 may be efficiently employed to both reduce and prevent neuroinflammatory responses in LPS-stimulated BV2 microglial cells. In addition, we observed that pretreatment with CA140 significantly reduced LPS-induced proinflammatory cytokine levels in rat primary microglia and primary astrocytes under high-glucose conditions (Additional file 1: Figure S6). However, post-treatment with CA140 only affected the LPS-stimulated proinflammatory response in rat primary microglial cells and not primary astrocytes under high-glucose conditions (Additional file 1: Figure S6). Why do pre- and post-treatment with CA140 have different effects on LPS-induced proinflammatory responses? Several recent studies have reported that high glucose levels induce primary glial cell activation [25-28]. Thus, we conducted additional experiments to assess the anti-inflammatory effects of CA140 on primary glial cells under low-glucose conditions. Pre- or post-treatment with CA140 significantly reduced LPS-stimulated proinflammatory cytokine levels in mouse primary microglial cells 


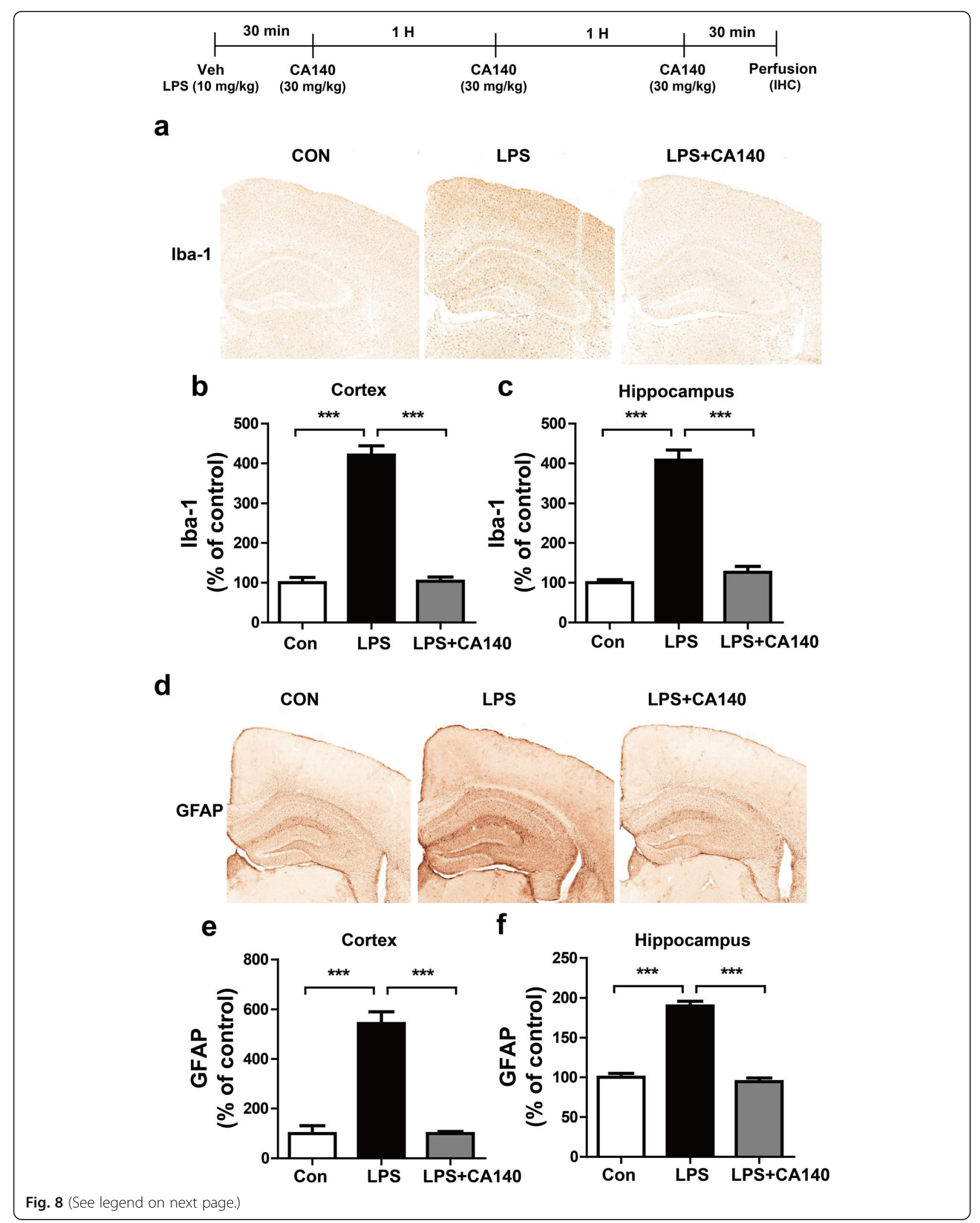


(See figure on previous page.)

Fig. 8 Pretreatment with LPS followed by CA140 treatment significantly decreased microglial and astrocyte activation in wild-type mice. a Wildtype mice were injected with LPS (10 mg/kg, i.p.), followed 30 min later by injection twice with CA140 (30 mg/kg, i.p.) at an interval of $1 \mathrm{~h}$ and a third injection (30 mg/kg, i.p.) at an interval of $30 \mathrm{~min}$. The mice were perfused, fixed, and immunostained with anti-lba-1 antibody. b, c Quantification of data from a (con, $n=5$ mice; LPS, $n=5$ mice; LPS + CA140, $n=5$ mice). $\mathbf{d}$ Wild-type mice were injected with LPS (10 mg/kg, i.p.), followed $30 \mathrm{~min}$ later by injection twice with CA140 (30 mg/kg, i.p.) at an interval of $1 \mathrm{~h}$ and a third injection (30 mg/kg, i.p.) at an interval of 30 min. The mice were perfused, fixed, and immunostained with anti-GFAP antibody. e, $\mathbf{f}$ Quantification of data from $\mathbf{d}$ (con, $n=5$ mice; LPS, $n=$ 5 mice; LPS + CA140, $n=5$ mice). ${ }^{* * *} p<0.0001$

under low-glucose conditions (Fig. 3a-f, Additional file 1: Figure S7). In addition, pretreatment with CA140 significantly reduced LPS-induced proinflammatory cytokine levels in mouse primary astrocytes (Additional file 1: Figure S7). Interestingly, post-treatment with CA140 only reduced LPS-induced iNOS mRNA levels in mouse primary astrocytes under low-glucose conditions (Fig. 3). These data suggest that pre- or post-treatment with CA140 may have different effects depending on cell type and culture conditions (e.g., low vs high glucose).

The physiological functions of the catecholaminergic neurotransmitter DA, which range from voluntary movement and reward to hormonal regulation and hypertension, are mediated by G-protein-coupled DA receptors (D1, D2, D3, D4, and D5) [39, 40]. DA receptors have also been identified as important factors for controlling immunity in the CNS [41]. Importantly, D1R and $\mathrm{D} 2 \mathrm{R}$ are expressed in rodent and human microglia from brains damaged by stroke or neurodegeneration [41-43]. Here, we observed that D1R and D2R were expressed in BV2 microglial cells and upregulated by LPS treatment (Additional file 1: Figure S8). Previous studies and our results may imply that the upregulation of DA receptors in microglia contributes to neuroinflammation in pathological conditions. Spiperone, a D1/D2R antagonist, inhibits DA-induced chemotaxis in cultured human microglia [44]. Pretreatment with SCH23390, an antagonist of D1R, suppresses NO production by microglia in LPS-injected mice [45]. Consistent with these findings, pretreatment with LE300 or SCH23390, antagonists of D1R, significantly suppressed COX-2 and IL-1 $\beta$ mRNA levels in LPS-stimulated BV2 microglial cells (Fig. 4). A68930, an agonist of D1R, inhibits the production of proinflammatory cytokines in mice [46], and pretreatment with SKF83959, an atypical D1R agonist, reduces proinflammatory cytokine levels in LPS-stimulated BV2 microglia [47]. However, in the present study, pretreatment with A77636, a selective agonist of D1R, did not reduce LPS-induced proinflammatory cytokine levels (Fig. 5). More importantly, treatment with A77636, LPS, and CA140 significantly suppressed LPS-stimulated IL-1 $\beta$ mRNA levels compared with treatment with A77636 and LPS, suggesting that CA140 regulates D1R to alter the LPS-induced neuroinflammatory response (Fig. 5).
With respect to the effects of D2R on neuroinflammation, the D2R agonist pramipexole increases nitrites in cultured primary microglia [42]. In addition, sulpiride, an antagonist of D2R, reduces LPS-induced TNF- $\alpha$ and $\mathrm{NO}$ production [45]. In astrocytes, D2R contributes to the suppression of neuroinflammation; however, microglial D2R is not involved in neuroinflammation according to studies of D2R-deficient mice or an ischemic mouse model $[48,49]$. In our study, the D2R antagonist eticlopride hydrochloride (EH) did not alter LPS-stimulated proinflammatory cytokine levels in BV2 microglial cells (Additional file 1: Figure S9). This discrepancy may be a result of differences in the details of the experimental procedures, such as treatment duration (i.e., $6 \mathrm{~h}$ compared with $24 \mathrm{~h}$ ), the effective dose of antagonist or agonist, and/or pre- or post-treatment with a DA receptor antagonist. Based on the existing literature and our current findings, we suggest that CA140 may directly or indirectly interact with D1R and thereby regulate neuroinflammatory responses. However, we do not exclude other possibilities; for example, CA140 may regulate other neuroinflammation-related receptors (e.g., TLR4, other DA receptors) to modulate neuroinflammatory responses. Additional studies are required to fully dissect the molecular mechanisms involved in the CA140/DA receptors-induced neuroinflammatory response in vivo.

Activation of TLR receptors via LPS turns on downstream signaling cascades, such as MAP kinases, including ERK and AKT signaling in microglia and astrocytes $[10,50,51]$. Therefore, inhibiting the MAP kinase signaling pathway has been suggested as a potential target for therapeutic drugs for anti-inflammation. Moreover, MAP kinase has been suggested as a downstream effector of both D1R and D2R stimulation [52, 53]. Treatment with the D1R agonist SKF 38393 and the D2R agonist quinpirole activates ERK signaling in primary cultured striatal neurons [54], and in cultured neuroblastoma cells, treatment with the D1R agonist SKF 38393 results in oxidative stress and cytotoxicity via ERK activation [55]. Interestingly, our results indicated that pre- or post-treatment with CA140 significantly suppressed LPS-stimulated ERK signaling in BV2 microglial cells (Fig. 6, Additional file 1: Figure S10). In addition, we found that CA140 further reduced proinflammatory 


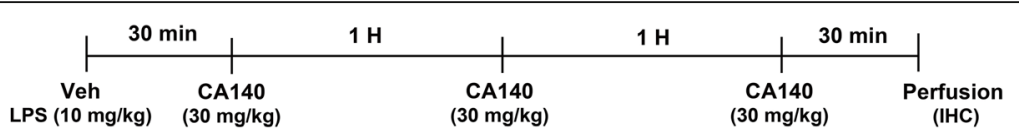

a Cortex

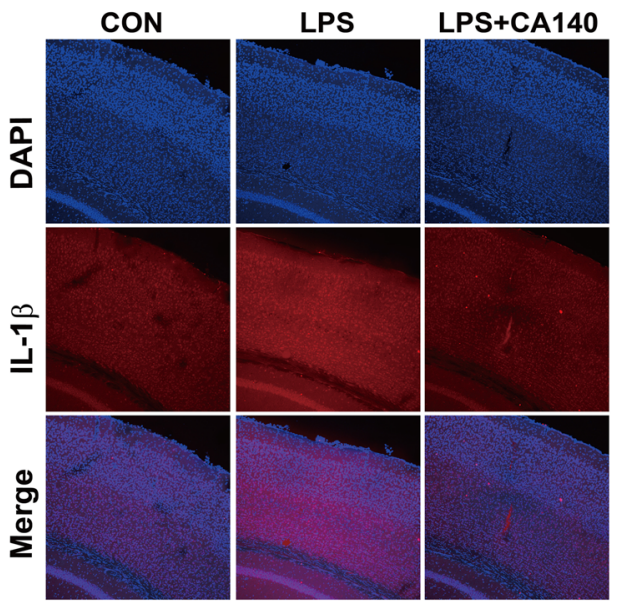

b

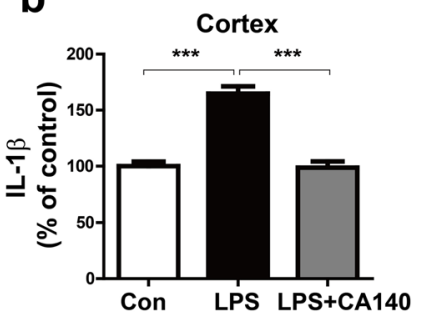

c Hippocampus
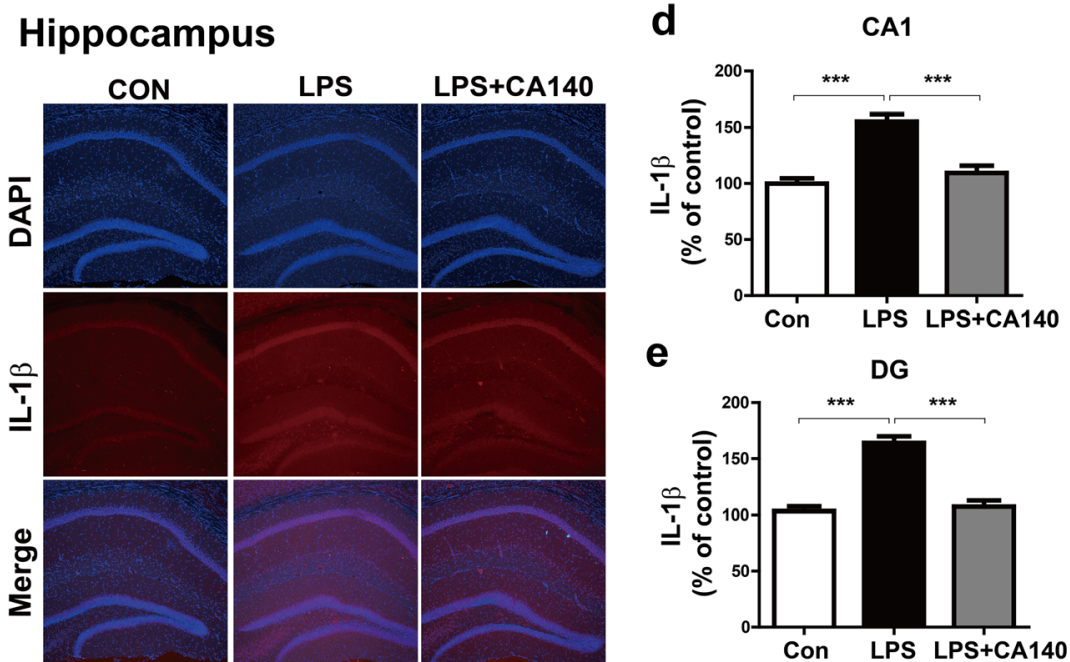

e

DG
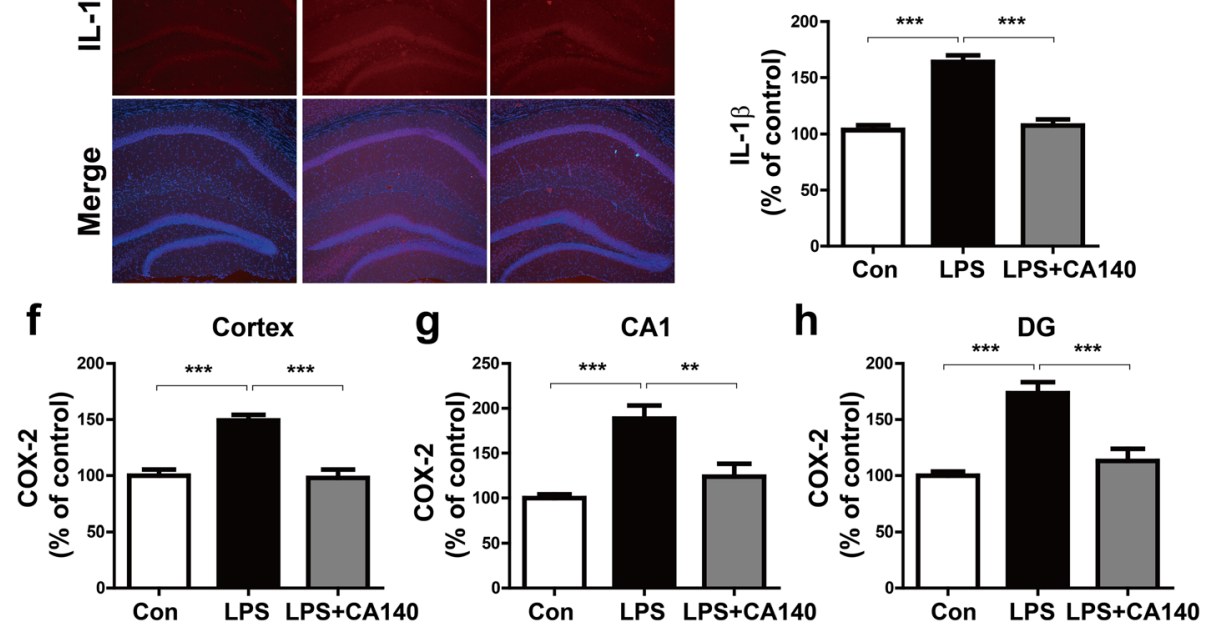

Fig. 9 Pretreatment with LPS followed by CA140 treatment significantly reduced IL-1 $\beta$ and COX-2 levels in wild-type mice. a, c Wild-type mice were injected with LPS (10 mg/kg, i.p.), followed $30 \mathrm{~min}$ later by injection twice with CA140 (30 mg/kg, i.p.) at an interval of $1 \mathrm{~h}$ and a third injection (30 mg/kg, i.p.) at an interval of $30 \mathrm{~min}$. The mice were perfused, fixed, and immunostained with anti-IL-1 $\beta$ antibody in the cortex (a) and hippocampus (c). b, d, e Quantification of data from a (cortex: con, $n=5$ mice; LPS, $n=5$ mice; LPS + CA140, $n=5$ mice) and $\mathbf{c}$ (hippocampus CA1 and DG: con, $n=5$ mice; LPS, $n=5$ mice; LPS + CA140, $n=5$ mice). $\mathbf{f}-\mathbf{h}$ Wild-type mice were injected with LPS (10 mg/kg, i.p.), followed $30 \mathrm{~min}$ later by injection twice with CA140 (30 mg/kg, i.p.) at an interval of $1 \mathrm{~h}$ and a third injection (30 mg/kg, i.p.) at an interval of 30 min. The mice were perfused, fixed, and immunostained with anti-IL-1 $\beta$ antibody in the cortex (con, $n=5$ mice; LPS, $n=5$ mice; LPS + CA140, $n=5$ mice), hippocampus CA1 (g, con, $n=5$ mice; LPS, $n=5$ mice; LPS + CA140, $n=5$ mice), and dentate gyrus (h, con, $n=5$ mice; LPS, $n=5$ mice; LPS + CA140, $n=5$ mice). ${ }^{* * *} p<0.0001$ 


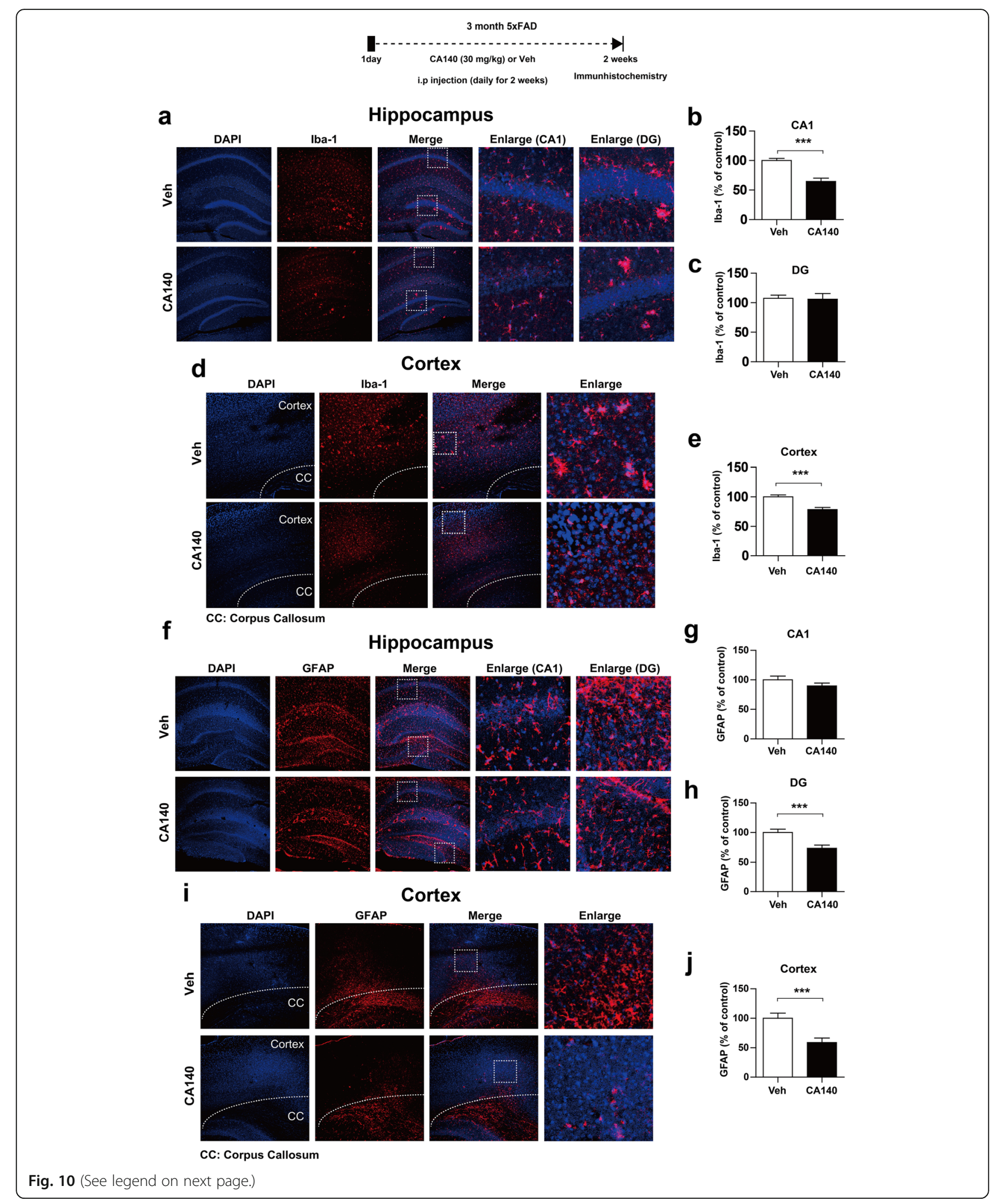


(See figure on previous page.)

Fig. 10 CA140 significantly reduced microglial and astrocyte activation in 5xFAD mice. a, d Representative images of the hippocampus (a) and cortex (d) from 5xFAD mice injected with vehicle (10\% DMSO, i.p.) or CA140 (30 mg/kg, i.p.) daily for 2 weeks; immunohistochemistry was performed with anti-Iba-1 antibody. b, c Quantification of data from a (hippocampus CA1 and DG: con, $n=8$ mice; CA140, $n=8$ mice). e Quantification of data from $\mathbf{d}$ (cortex: con, $n=8$ mice; CA140, $n=8$ mice). f, i Representative images of the hippocampus (f) and cortex (i) from 5xFAD mice injected with vehicle (10\% DMSO, i.p.) or CA140 (30 mg/kg, i.p.) daily for 2 weeks; immunohistochemistry was performed with antiGFAP antibody. $\mathbf{g}, \mathbf{h}$ Quantification of data from $\mathbf{f}$ (hippocampus CA1 and DG: con, $n=6$ mice; CA140, $n=6$ mice). $\mathbf{j}$ Quantification of data from $\mathbf{i}$ (cortex: con, $n=6$ mice; CA140, $n=6$ mice). ${ }^{* * *} p<0.0001$

cytokine levels when combined with an ERK inhibitor, which suggests that CA140 alters LPS-induced ERK phosphorylation to modify the neuroinflammatory response.

STAT3, a member of the STAT family, is a transcription factor that plays a critical role in regulating microglial activation and inflammatory responses [56, 57]. STAT3 levels in microglia are enhanced in brain injury and a neurodegenerative disease model $[58,59]$. Thus, we examined whether CA140 alters the nuclear localization of STAT3 to regulate the neuroinflammatory response and found that pre- or post-treatment with CA140 reduced cytosolic and nuclear p-STAT3 levels in LPS-stimulated BV2 microglial cells (Fig. 7, Additional file 1: Figure S11). Taken together, our data suggest that CA140 may alter neuroinflammation by regulating the ERK/STAT3 signaling pathway.

Systemic injection of LPS in wild-type mice significantly induces astrocyte and microglial activation and proinflammatory cytokine expression [60-62]. Moreover, a single injection of LPS induces robust expression of IL- $1 \beta$ and TNF- $\alpha$ mRNA in various brain regions of wild-type mice [63]. Intracerebral LPS injection in rats induces inflammatory responses and $\beta$-secretase-1 (BACE1) in the cortex and hippocampus, with axonal and dendritic pathologies similar to those present in $\mathrm{AD}[64,65]$. Other studies have also demonstrated that LPS treatment exacerbates the accumulation of amyloid beta and tau pathology in a mouse model of $\mathrm{AD}[59,66,67]$. Interestingly, a recent study has shown that both SCH23390, a D1R antagonist, and sulpiride, a D2R antagonist, suppress proinflammatory cytokine levels in LPS-injected mice [45]. DA released by electroacupuncture reduces proinflammatory cytokine levels through D1R in LPS-injected mice [68]. In addition, the regulation of catecholamines by pharmacological agents, such as methylphenidate, enhances neuroinflammatory responses and microgliosis in 5xFAD mice, a transgenic $\mathrm{AD}$ mouse model $[32,69]$. In the present study, our novel drug CA140, which is structurally related to DA, also substantially reduced astrocyte and microglial activation as well as proinflammatory cytokine levels in LPS-injected wild-type mice and 5xFAD mice (Fig. 8-10, Additional file 1: Figure S12). Taken together, our results suggest that
CA140 may serve as a therapeutic agent for the prevention/treatment of neuroinflammation-related diseases, including $\mathrm{AD}$.

\section{Conclusions}

In the present study, we have demonstrated that CA140 exhibits novel anti-inflammatory effects and provided initial evidence for its mechanism of action. We discovered that CA140 suppresses LPS-induced proinflammatory cytokine levels in BV2 microglial cells, primary microglia, and primary astrocytes. In addition, CA140 modulates D1R to regulate LPS-induced neuroinflammation in BV2 microglial cells. Moreover, CA140 affects ERK/STAT3 signaling to alter the LPS-induced neuroinflammatory response. In in vivo experiments, CA140 significantly reduced microglial and astrocyte activation in LPS-injected wild-type mice and $5 x F A D$ mice. This study reveals that CA140 is a promising compound with anti-inflammatory effects and subsequent attenuation of neurotoxins such as LPS.

\section{Additional file}

Additional file 1: Figure S1. Post-treatment with CA140 at $5 \mu \mathrm{M}$ only significantly reduced LPS-induced IL-1 $\beta$ mRNA levels. Figure S2. Posttreatment with CA140 significantly reduced LPS-induced proinflammatory cytokine levels in a longer treatment. Figure S3. Pretreatment with CA140 significantly decreased LPS-induced COX-2, IL-1 $\beta$, and iNOS mRNA levels in BV2 microglial cells. Figure S4. Pretreatment with CA140 significantly decreased LPS-induced COX-2, IL-1 $\beta$, and iNOS mRNA levels in a longer treatment. Figure S5. Post-treatment with CA140 significantly decreased LPS-mediated proinflammatory cytokine levels in rat primary microglial cells. Figure S6. Pretreatment with CA140 decreased LPS-induced proinflammatory cytokine levels in rat primary microglial cells and primary astrocytes. Figure S7. Pretreatment with CA140 decreased LPS-mediated proinflammatory cytokine levels in mouse primary microglial cells and primary astrocytes. Figure S8. Post-treatment with CA140 downregulated LPS-induced dopamine D1 receptor (D1R) levels in BV2 microglial cells. Figure S9. Inhibition of dopamine D2 receptor (D2R) did not reduce LPSstimulated proinflammatory cytokine levels in BV2 microglial cells. Figure S10 Pretreatment with CA140 significantly decreased phosphorylation of ERK and AKT in LPS-stimulated BV2 microglial cells. Figure S11. Pretreatment with CA140 significantly decreased cytosolic and nuclear p-STAT3 levels in LPS-induced BV2 microglial cells. Figure S12. Pretreatment with CA140 significantly reduced microglia and astrocyte activation in wildtype mice. (DOCX $22915 \mathrm{~kb}$ )

\section{Abbreviations}

AD: Alzheimer's disease; BBB: Blood-brain barrier; CNS: Central nervous system; D1R: Dopamine D1 receptor; D2R: Dopamine D2 receptor; DA: Dopamine; ERK: Extracellular signal-regulated kinase; IL-1 $\beta$ : Interleukin-1 $\beta$; JNK: c-Jun N-terminal kinase; LPS: Lipopolysaccharide; MAPK: Mitogen- 
activated protein kinase; TLR4: Toll-like receptor 4; TNF-a: Tumor necrosis factor-a

\section{Acknowledgements}

Confocal microscopy (Nikon, TI-RCP) and bright-field microscopy (Carl Zeiss) data were acquired at the Advanced Neural Imaging Center of the Korea Brain Research Institute (KBRI).

\section{Ethical approval and consent to participate}

All animal experiments were performed in accordance with the approved animal protocols and guidelines established by the Korea Brain Research Institute Animal Care and Use Committee (IACUC-2016-0013). Consent to participate of human subjects is not applicable in this study.

\section{Funding}

This work was supported by the KBRI basic research program through KBRI funded by the Ministry of Science, ICT and Future Planning (grant number 18-BR-02-04, H.S.H.), the National Research Foundation of Korea (grant number 2016R1A2B4011393, H.S.H.), and the National Research Council of Science and Technology (grant number CAP-12-1-KIST, W.G.C.). Research reported in this publication was also supported by the National Institute on Aging of the National Institutes of Health under Award Number R01AG053577 (M.R.B., C.C.C., T.K., and J.Y.).

\section{Availability of data and materials}

All data generated and/or analyzed during this study are included in this article.

\section{Authors' contributions}

$J Y L, H G C, J Y, J K$, and HSH conceived the study, participated in the design of the study, and wrote the manuscript. JYL, JHN, and HYN performed molecular/cellular experiments, in vivo experiments, and statistical analyses. EK, SBK, and HGC performed blood-brain barrier experiments. MRB, CCC, TK $\mathrm{GL}$, and JY synthesized and developed CA140. YPN and GY conducted the ELISA studies (CAMP, IL-1 $\beta, N O$ ), time-dependent experiments, functional as says of CA140/DIR by treatment with DIR agonist or antagonist in vitro and in vivo, and data analysis and contributed to writing the revised manuscript. All authors read and approved the final manuscript.

\section{Consent for publication}

Not applicable

\section{Competing interests}

The authors declare that they have no competing interests.

\section{Publisher's Note}

Springer Nature remains neutral with regard to jurisdictional claims in published maps and institutional affiliations.

\section{Author details}

${ }^{1}$ Department of Neural Development and Disease, Korea Brain Research Institute (KBRI), 61 Cheomdan-ro, Dong-gu, Daegu 41068, South Korea. ${ }^{2} \mathrm{New}$ Drug Development Center, Daegu-Gyeongbuk Medical Innovation Foundation, 80 Cheombok-ro, Dong-gu, Daegu 41061, South Korea. ${ }^{3}$ Department of Chemistry and Biochemistry, University of California, San Diego, La Jolla, CA 92093-0358, USA.

Received: 8 May 2018 Accepted: 19 September 2018

Published online: 11 October 2018

\section{References}

1. Balducci C, Forloni G. Novel targets in Alzheimer's disease: a special focus on microglia. Pharmacol Res. 2018.

2. Fan Z, Okello AA, Brooks DJ, Edison P. Longitudinal influence of microglial activation and amyloid on neuronal function in Alzheimer's disease. Brain. 2015;138:3685-98

3. Kirkley KS, Popichak KA, Afzali MF, Legare ME, Tjalkens RB. Microglia amplify inflammatory activation of astrocytes in manganese neurotoxicity. J Neuroinflammation. 2017;14:99.

4. La Rosa F, Saresella M, Baglio F, Piancone F, Marventano I, Calabrese E, Nemni R, Ripamonti E, Cabinio M, Clerici M. Immune and imaging correlates of mild cognitive impairment conversion to Alzheimer's disease. Sci Rep. 2017;7:16760.

5. Badshah H, Ali T, Kim MO. Osmotin attenuates LPS-induced neuroinflammation and memory impairments via the TLR4/NFkappaB signaling pathway. Sci Rep. 2016;6:24493.

6. Li JJ, Wang B, Kodali MC, Chen C, Kim E, Patters BJ, Lan L, Kumar S, Wang X, Yue J, Liao FF. In vivo evidence for the contribution of peripheral circulating inflammatory exosomes to neuroinflammation. J Neuroinflammation. 2018;15:8.

7. Lester SN, Li K. Toll-like receptors in antiviral innate immunity. J Mol Biol. 2014:426:1246-64.

8. Cheng B, Lin Y, Kuang M, Fang S, Gu Q, Xu J, Wang L. Synthesis and antineuroinflammatory activity of lactone benzoyl hydrazine and 2-nitro-1phenyl-1h-indole derivatives as p38alpha MAPK inhibitors. Chem Biol Drug Des. 2015;86:1121-30.

9. Xu P, Huang MW, Xiao CX, Long F, Wang Y, Liu SY, Jia WW, Wu WJ, Yang D, $\mathrm{Hu} J \mathrm{JF}$, et al. Matairesinol suppresses neuroinflammation and migration associated with Src and ERK1/2-NF-kappaB pathway in activating BV2 microglia. Neurochem Res. 2017;42:2850-60.

10. Guo C, Yang L, Wan CX, Xia YZ, Zhang C, Chen MH, Wang ZD, Li ZR, Li XM, Geng YD, Kong LY. Anti-neuroinflammatory effect of Sophoraflavanone G from Sophora alopecuroides in LPS-activated BV2 microglia by MAPK, JAK STAT and Nrf2/HO-1 signaling pathways. Phytomedicine. 2016;23:1629-37.

11. Choo XY, Alukaidey L, White AR, Grubman A. Neuroinflammation and copper in Alzheimer's disease. Int J Alzheimers Dis. 2013;2013:145345.

12. Schlachetzki JC, Hull M. Microglial activation in Alzheimer's disease. Curr Alzheimer Res. 2009:6:554-63.

13. Fang $X X$, Sun $G L$, Zhou Y, Qiu YH, Peng YP. TGF-beta1 protection against Abeta1-42-induced hippocampal neuronal inflammation and apoptosis by TbetaR-I. Neuroreport. 2018;29:141-6.

14. Valles SL, Dolz-Gaiton P, Gambini J, Borras C, Lloret A, Pallardo FV, Vina J. Estradiol or genistein prevent Alzheimer's disease-associated inflammation correlating with an increase PPAR gamma expression in cultured astrocytes. Brain Res. 2010;1312:138-44.

15. von Bernhardi R. Glial cell dysregulation: a new perspective on Alzheimer disease. Neurotox Res. 2007;12:215-32.

16. Liu Y, Ai K, Lu L. Polydopamine and its derivative materials: synthesis and promising applications in energy, environmental, and biomedical fields. Chem Rev. 2014;114:5057-115.

17. Grigoryan G, Hodges H, Mitchell S, Sinden JD, Gray JA. 6-OHDA lesions of the nucleus accumbens accentuate memory deficits in animals with lesions to the forebrain cholinergic projection system: effects of nicotine administration on learning and memory in the water maze. Neurobiol Learn Mem. 1996:65:135-53.

18. Femenia T, Qian Y, Arentsen T, Forssberg H, Diaz Heijtz R. Toll-like receptor-4 regulates anxiety-like behavior and DARPP-32 phosphorylation. Brain Behav Immun. 2017.

19. Basu B, Sarkar C, Chakroborty D, Ganguly S, Shome S, Dasgupta PS, Basu S. D1 and D2 dopamine receptor-mediated inhibition of activated normal T cell proliferation is lost in T leukemic cells, Jurkat. J Biol Chem. 2010;285:27026-32.

20. Lee S, Park JY, Lee WH, Kim H, Park HC, Mori K, Suk K. Lipocalin-2 is an autocrine mediator of reactive astrocytosis. J Neurosci. 2009;29:234-49.

21. Saura J, Tusell JM, Serratosa J. High-yield isolation of murine microglia by mild trypsinization. Glia. 2003;44:183-9.

22. Nam JH, Cho HJ, Kang H, Lee JY, Jung M, Chang YC, Kim K, Hoe HS. A mercaptoacetamide-based class II histone deacetylase inhibitor suppresses cell migration and invasion in monomorphic malignant human glioma cells by inhibiting FAK/STAT3 signaling. J Cell Biochem. 2017:118:4672-85.

23. Song JM, Sung YM, Nam JH, Yoon H, Chung A, Moffat E, Jung M, Pak DT, Kim J, Hoe HS. A mercaptoacetamide-based class II histone deacetylase inhibitor increases dendritic spine density via RasGRF1/ERK pathway. J Alzheimers Dis. 2016;51:591-604.

24. Henn A, Lund S, Hedtjarn M, Schrattenholz A, Porzgen P, Leist M. The suitability of BV2 cells as alternative model system for primary microglia cultures or for animal experiments examining brain inflammation. ALTEX. 2009;26:83-94.

25. Wang J, Li G, Wang Z, Zhang X, Yao L, Wang F, Liu S, Yin J, Ling EA, Wang L, Hao A. High glucose-induced expression of inflammatory cytokines and reactive oxygen species in cultured astrocytes. Neuroscience. 2012;202:58-68.

26. Nagai K, Fukushima T, Oike H, Kobori M. High glucose increases the expression of proinflammatory cytokines and secretion of TNFalpha and beta-hexosaminidase in human mast cells. Eur J Pharmacol. 2012;687:39-45. 
27. Quincozes-Santos A, Bobermin LD, de Assis AM, Goncalves CA, Souza DO. Fluctuations in glucose levels induce glial toxicity with glutamatergic, oxidative and inflammatory implications. Biochim Biophys Acta. 1863;2017:1-14.

28. Lange SC, Bak LK, Waagepetersen HS, Schousboe A, Norenberg MD. Primary cultures of astrocytes: their value in understanding astrocytes in health and disease. Neurochem Res. 2012;37:2569-88.

29. Kim EK, Choi EJ. Compromised MAPK signaling in human diseases: an update. Arch Toxicol. 2015;89:867-82.

30. Fourrier C, Remus-Borel J, Greenhalgh AD, Guichardant M, Bernoud-Hubac $\mathrm{N}$, Lagarde M, Joffre C, Laye S. Docosahexaenoic acid-containing choline phospholipid modulates LPS-induced neuroinflammation in vivo and in microglia in vitro. J Neuroinflammation. 2017;14:170.

31. Bellaver B, Souza DG, Bobermin LD, Goncalves CA, Souza DO, QuincozesSantos A. Guanosine inhibits LPS-induced pro-inflammatory response and oxidative stress in hippocampal astrocytes through the heme oxygenase-1 pathway. Purinergic Signal. 2015;11:571-80.

32. Ardestani PM, Evans AK, Yi B, Nguyen T, Coutellier L, Shamloo M. Modulation of neuroinflammation and pathology in the 5XFAD mouse model of Alzheimer's disease using a biased and selective beta- 1 adrenergic receptor partial agonist. Neuropharmacology. 2017;116:371-86.

33. Benzing WC, Wujek JR, Ward EK, Shaffer D, Ashe KH, Younkin SG, Brunden KR. Evidence for glial-mediated inflammation in aged APP(SW) transgenic mice. Neurobiol Aging. 1999;20:581-9

34. Frank-Cannon TC, Alto LT, MCAlpine FE, Tansey MG. Does neuroinflammation fan the flame in neurodegenerative diseases? Mol Neurodegener. 2009;4:47.

35. Downen M, Amaral TD, Hua LL, Zhao ML, Lee SC. Neuronal death in cytokine-activated primary human brain cell culture: role of tumor necrosis factor-alpha. Glia. 1999;28:114-27.

36. Norden DM, Godbout JP. Review: microglia of the aged brain: primed to be activated and resistant to regulation. Neuropathol Appl Neurobiol. 2013;39:19-34.

37. Font-Nieves M, Sans-Fons MG, Gorina R, Bonfill-Teixidor E, Salas-Perdomo A, Marquez-Kisinousky L, Santalucia T, Planas AM. Induction of COX-2 enzyme and down-regulation of COX-1 expression by lipopolysaccharide (LPS) control prostaglandin E2 production in astrocytes. J Biol Chem. 2012;287:6454-68.

38. Parajuli B, Sonobe Y, Kawanokuchi J, Doi Y, Noda M, Takeuchi H, Mizuno T, Suzumura A. GM-CSF increases LPS-induced production of proinflammatory mediators via upregulation of TLR4 and CD14 in murine microglia. J Neuroinflammation. 2012;9:268.

39. Missale C, Nash SR, Robinson SW, Jaber M, Caron MG. Dopamine receptors: from structure to function. Physiol Rev. 1998;78:189-225.

40. Beaulieu JM, Gainetdinov RR. The physiology, signaling, and pharmacology of dopamine receptors. Pharmacol Rev. 2011;63:182-217.

41. Pocock JM, Kettenmann H. Neurotransmitter receptors on microglia. Trends Neurosci. 2007;30:527-35.

42. Huck JH, Freyer D, Bottcher C, Mladinov M, Muselmann-Genschow C, Thielke M, Gladow N, Bloomquist D, Mergenthaler P, Priller J. De novo expression of dopamine D2 receptors on microglia after stroke. J Cereb Blood Flow Metab. 2015:35:1804-11.

43. Farber K, Pannasch U, Kettenmann H. Dopamine and noradrenaline control distinct functions in rodent microglial cells. Mol Cell Neurosci. 2005;29:128-38.

44. Mastroeni D, Grover A, Leonard B, Joyce JN, Coleman PD, Kozik B, Bellinger $\mathrm{DL}$, Rogers J. Microglial responses to dopamine in a cell culture model of Parkinson's disease. Neurobiol Aging. 2009;30:1805-17.

45. Hasko G, Szabo C, Merkel K, Bencsics A, Zingarelli B, Kvetan V, Vizi ES. Modulation of lipopolysaccharide-induced tumor necrosis factor-alpha and nitric oxide production by dopamine receptor agonists and antagonists in mice. Immunol Lett. 1996;49:143-7.

46. Wang T, Nowrangi D, Yu L, Lu T, Tang J, Han B, Ding Y, Fu F, Zhang JH. Activation of dopamine D1 receptor decreased NLRP3-mediated inflammation in intracerebral hemorrhage mice. J Neuroinflammation. 2018;15:2.

47. Wu Z, Li L, Zheng LT, Xu Z, Guo L, Zhen X. Allosteric modulation of sigma-1 receptors by SKF83959 inhibits microglia-mediated inflammation. J Neurochem. 2015;134:904-14.

48. Shao W, Zhang $S Z$, Tang $M$, Zhang $X H$, Zhou Z, Yin YQ, Zhou QB, Huang YY, Liu YJ, Wawrousek E, et al. Suppression of neuroinflammation by astrocytic dopamine D2 receptors via alphaB-crystallin. Nature. 2013;494:90-4.

49. Qiu J, Yan Z, Tao K, Li Y, Li Y, Li J, Dong Y, Feng D, Chen H. Sinomenine activates astrocytic dopamine D2 receptors and alleviates neuroinflammatory injury via the CRYAB/STAT3 pathway after ischemic stroke in mice. J Neuroinflammation. 2016;13:263.
50. Dang Y, Xu Y, Wu W, Li W, Sun Y, Yang J, Zhu Y, Zhang C. Tetrandrine suppresses lipopolysaccharide-induced microglial activation by inhibiting NFkappaB and ERK signaling pathways in BV2 cells. PLoS One. 2014;9:e102522.

51. Kaminska B, Gozdz A, Zawadzka M, Ellert-Miklaszewska A, Lipko M. MAPK signal transduction underlying brain inflammation and gliosis as therapeutic target. Anat Rec (Hoboken). 2009;292:1902-13.

52. Yan Z, Feng J, Fienberg AA, Greengard P. D(2) dopamine receptors induce mitogen-activated protein kinase and CAMP response element-binding protein phosphorylation in neurons. Proc Natl Acad Sci U S A. 1999;96: 11607-12.

53. Zanassi P, Paolillo M, Feliciello A, Avvedimento EV, Gallo V, Schinelli S. CAMPdependent protein kinase induces CAMP-response element-binding protein phosphorylation via an intracellular calcium release/ERK-dependent pathway in striatal neurons. J Biol Chem. 2001;276:11487-95.

54. Brami-Cherrier K, Valjent E, Garcia M, Pages C, Hipskind RA, Caboche J. Dopamine induces a PI3-kinase-independent activation of Akt in striatal neurons: a new route to CAMP response element-binding protein phosphorylation. J Neurosci. 2002;22:8911-21.

55. Chen J, Rusnak M, Luedtke RR, Sidhu A. D1 dopamine receptor mediates dopamine-induced cytotoxicity via the ERK signal cascade. J Biol Chem. 2004;279:39317-30.

56. Huang C, Ma R, Sun S, Wei G, Fang Y, Liu R, Li G. JAK2-STAT3 signaling pathway mediates thrombin-induced proinflammatory actions of microglia in vitro. J Neuroimmunol. 2008;204:118-25.

57. Dinapoli VA, Benkovic SA, Li X, Kelly KA, Miller DB, Rosen CL, Huber JD, O'Callaghan JP. Age exaggerates proinflammatory cytokine signaling and truncates signal transducers and activators of transcription 3 signaling following ischemic stroke in the rat. Neuroscience. 2010;170:633-44.

58. Chen S, Dong Z, Cheng M, Zhao Y, Wang M, Sai N, Wang X, Liu H, Huang G, Zhang $X$. Homocysteine exaggerates microglia activation and neuroinflammation through microglia localized STAT3 overactivation following ischemic stroke. J Neuroinflammation. 2017;14:187.

59. Carret-Rebillat AS, Pace C, Gourmaud S, Ravasi L, Montagne-Stora S, Longueville S, Tible M, Sudol E, Chang RC, Paquet C, et al. Neuroinflammation and Abeta accumulation linked to systemic inflammation are decreased by genetic PKR down-regulation. Sci Rep. 2015:5:8489

60. Qin L, Wu X, Block ML, Liu Y, Breese GR, Hong JS, Knapp DJ, Crews FT. Systemic LPS causes chronic neuroinflammation and progressive neurodegeneration. Glia. 2007;55:453-62.

61. Jeong HK, Jou I, Joe EH. Systemic LPS administration induces brain inflammation but not dopaminergic neuronal death in the substantia nigra. Exp Mol Med. 2010;42:823-32.

62. Catorce MN, Gevorkian G. LPS-induced murine neuroinflammation model: main features and suitability for pre-clinical assessment of nutraceuticals. Curr Neuropharmacol. 2016;14:155-64.

63. Skelly DT, Hennessy E, Dansereau MA, Cunningham C. A systematic analysis of the peripheral and CNS effects of systemic LPS, IL-1 beta, [corrected] TNFalpha and IL-6 challenges in C57BL/6 mice. PLoS One. 2013;8:e69123.

64. Deng X, Li M, Ai W, He L, Lu D, Patrylo PR, Cai H, Luo X, Li Z, Yan X. Lipolysaccharide-induced neuroinflammation is associated with Alzheimerlike amyloidogenic axonal pathology and dendritic degeneration in rats. Adv Alzheimer Dis. 2014:3:78-93.

65. Kitazawa M, Oddo S, Yamasaki TR, Green KN, LaFerla FM. Lipopolysaccharide-induced inflammation exacerbates tau pathology by a cyclin-dependent kinase 5-mediated pathway in a transgenic model of Alzheimer's disease. J Neurosci. 2005;25:8843-53.

66. Lee DC, Rizer J, Hunt JB, Selenica ML, Gordon MN, Morgan D. Review: experimental manipulations of microglia in mouse models of Alzheimer's pathology: activation reduces amyloid but hastens tau pathology. Neuropathol Appl Neurobiol. 2013:39:69-85.

67. LaFerla FM, Green KN. Animal models of Alzheimer disease. Cold Spring Harb Perspect Med. 2012;2.

68. Torres-Rosas R, Yehia G, Pena G, Mishra P, del Rocio T-BM, Moreno-Eutimio MA, Arriaga-Pizano LA, Isibasi A, Ulloa L. Dopamine mediates vagal modulation of the immune system by electroacupuncture. Nat Med. 2014;20:291-5.

69. Schneider F, Baldauf K, Wetzel W, Reymann KG. Effects of methylphenidate on the behavior of male 5xFAD mice. Pharmacol Biochem Behav. 2015;128:68-77. 